INTERNATIONAL

FOOD POLICY

RESEARCH

INSTITUTE

IFPRI

IFPRI Discussion Paper 01700

December 2017

Political Activism as a Determinant of Clientelistic Transfers

Evidence from an Indian Public Works Program

Nancy H. Chau

Yanyan Liu

Vidhya Soundararajan

Markets, Trade, and Institutions Division 


\section{INTERNATIONAL FOOD POLICY RESEARCH INSTITUTE}

The International Food Policy Research Institute (IFPRI), established in 1975, provides evidence-based policy solutions to sustainably end hunger and malnutrition and reduce poverty. The Institute conducts research, communicates results, optimizes partnerships, and builds capacity to ensure sustainable food production, promote healthy food systems, improve markets and trade, transform agriculture, build resilience, and strengthen institutions and governance. Gender is considered in all of the Institute's work. IFPRI collaborates with partners around the world, including development implementers, public institutions, the private sector, and farmers' organizations, to ensure that local, national, regional, and global food policies are based on evidence.

\section{AUTHORS}

Nancy Chau (hyc3@cornell.edu) is a Professor in the Dyson School of Applied Economics and Management at Cornell University, Ithaca, NY.

Yanyan Liu (y.liu@cgiar.org) is Senior Research Fellow in the Markets, Trade, and Institutions Division of the International Food Policy Research Institute, Washington, DC.

Vidhya Soundararajan (vidhyasrajan@iimb.ernet.in) is Assistant Professor in the Economics and Social Sciences Area of the Indian Institute of Management Bangalore, Bengaluru, India.

\section{Notices}

${ }^{1}$ IFPRI Discussion Papers contain preliminary material and research results and are circulated in order to stimulate discussion and critical comment. They have not been subject to a formal external review via IFPRI's Publications Review Committee. Any opinions stated herein are those of the author(s) and are not necessarily representative of or endorsed by the International Food Policy Research Institute.

${ }^{2}$ The boundaries and names shown and the designations used on the map(s) herein do not imply official endorsement or acceptance by the International Food Policy Research Institute (IFPRI) or its partners and contributors.

${ }^{3}$ Copyright remains with the authors. 


\section{Contents}

Abstract $\quad$ vi

Acknowledgments $\quad$ vi

1 Introduction 1

2 Andhra Pradesh and the National Rural Employment Guarantee Scheme 7

3 A Simple Model of Political Clientelism 9

4 Data Description $\quad 18$

5 Empirical Methodology 22

6 Results 26

7 Conclusion $\quad 35$

References $\quad 36$

$\begin{array}{ll}\text { Appendix } & 53\end{array}$ 


\section{Tables}

$\begin{array}{lll}\text { Table } 1 \quad \text { Descriptive Statistics } & 44\end{array}$

Table 2 Political Categories and NREGS Outcomes in UPA-Sarpanch Villages 45

Table 3 Tobit Regression of NREGS Benefits on Political Affiliation and Political Activism in UPA-Sarpanch Villages 46

Table 4 Probit Regression of Job-Card Ownership on Political Affiliation and Political Activism in UPA-Sarpanch Villages

Table 5 Tobit regression of NREGS Benefits on Political Affiliation and Political Activism in non-UPA Sarpanch Villages

Table 6 Testing the Mechanism of Spill-Over Effects from Politically Active to Politically Inactive Group. Tobit Regression results in UPA-Sarpanch Villages

Table 7 Supporting Results for Spill-Over Effects. Tobit Regression of Log Days on Political Categories and Interaction of Active Village Connectedness Characteristics

Table 8 Tobit Regression of NREGS Benefits on Political Affiliation and Poligical Activism, and UPA-Dominance in UPA-Sarpanch Villages

Table 9 Controlling for Additional Political Variables. Marginal Effects from Tobit Regression Results in UPA-Sarpanch Villages

Table A1 Marginal Effects of Political Categories on NREGS Benefits, and their Corresponding Percentage Changes in UPA-Sarpanch Villages

Table A2 Tobit Regression of Log Days and Payment on Political Categories with and without Control Variables

Table A3 Political categories by Caste and Povery Characteristics

Table A4 Tobit Regression of NREGS Benefits on Poligical Categories for Participating Households, and the Corresponding Heckman Selection Correction Model in UPA-Sarpanch Villages

Table A5 Descriptive Statistics in non-UPA-Sarpanch Villages

Table A6 Robustness Check, Dropping Households That Got Jobs or Job-Cards Between February 2006 and the Interview Month. Marginal Effects from Tobit Regression Results in UPA-Sarpanch Villages

Table A7 Controlling for Other Public Program Transfers. Marginal Effects from Tobit Regression Results in UPA-Sarpanch Villages

Table A8 Marginal Effects of NREGS Benefits on Political Affiliation and Political Activism in UPA-Sarpanch villages, by Telangana and non-Telangana Districts

Table A9 Robustness Check, Refining Political Categories as Ver7-active and Less-active. Marginal Effects from Tobit Regression Results in UPA-Sarpanch Villages

Table A10 Supporting Results for Spill-Over Effects; Tobit Regression of Log Payment on Political Categories and Interaction of Active and Village Connectedness Characteristics

Talbe A11 Ordinary Least Squares Regression of Voting Behavior on Political Affiliation and Political Activism 


\section{Figures}

Figure $1 \quad$ Implementation and Institutional Details of DREGS 42

Figure 2 Timeline of Events 


\title{
Political Activism as a Determinant of Clientelistic Transfers: Evidence from an Indian Public Works Program*
}

\author{
Nancy H. Chau ${ }^{\dagger} \quad$ Yanyan Liu $\quad$ Vidhya Soundararajan ${ }^{\S}$
}

December 2017

\begin{abstract}
Are political activists preferentially targeted by politicians engaging in clientelistic transfers to bolster political support? We provide the first model to highlight two possible rationales for such transfers: to mobilize support from the activists themselves, or to mobilize support from electors these activists have influence over. Using novel household data on ex ante political affiliation and jobs received subsequent to large-scale decentralized workfare program in India, we find that activists are indeed preferentially targeted, and furthermore, such transfers are more pronounced in locations where citizen political involvement is less common, and in remote and less connected areas where activists' role in information transfers is most critical. We argue that the evidence is consistent with the use of transfers to leverage the influence of activists over the decision-making of other electors. Our results are not driven by self selection, reverse causality, and other program transfers, and are robust to alternate definitions of "activism".
\end{abstract}

JEL Classification: D7, H5.

Keywords: Political Clientelism, Political Activism, NREGS, India.

${ }^{*}$ We gratefully acknowledge the funding support from 3ie (International Initiative for Impact Evaluation) and CGIAR-Policies, Institutions and Markets (PIM) Program. We thank Siwan Anderson, Kate Ambler, Maria Casanova, Mausumi Das, Upasak Das, Sylvan Herskowitz, Vegard Iversen, Jordan Kyle, Diego Maiorano, Dilip Mookherjee, Danielle Resnick, Megan Sheahan, Rohini Somanathan and seminar audience at Cornell University, Indian Institute of Management Bangalore, Delhi School of Economics, Indian Statistical Institute Delhi, California State University Fullerton, Eastern Economics Association Conference 2017, Indian Institute of Technology Kanpur, Soceity for Economics Research in India, and International Food Policy Research Institute for discussions and feedback. All errors are our own.

${ }^{\dagger}$ Cornell University. Email:hyc3@cornell.edu

${ }^{\ddagger}$ International Food Policy Research Institute. Email:y.liu@cgiar.org

$\S$ Indian Institute of Management Bangalore. Email:vidhyasrajan@iimb.ernet.in 


\section{Introduction}

Political parties are known to strategically redirect public resources through decentralized programs to secure and expand their party base. In a large and long-standing literature, such activities have been referred to as tactical redistribution and/or political clientelism (Downs, 1957; Wright, 1974; Wyatt, 2013; Dixit and Londregan, 1996). In classic probability voting models, politicians target swing voters, who are closest to the center of the political spectrum, because transfers to this group lead to a greater increase in political support than transfers to groups with more extreme ideological attachments (Lindbek and Weibull, 1987; Dixit and Londregan, 1996, 1998; Stokes, 2005). Preferential targeting is also based on other elector characteristics such as political affiliation (Cox and McCubbins, 1986) and the tendency for reciprocal behavior (Finan and Schechter, 2012). Notably, citizens in these earlier studies play an exclusively passive role: they simply receive political transfers and choose party allegiance, and are otherwise not involved in politics. However, this limited role is inconsistent with a multitude of other activities in which electors may be involved; thus, it does not tell the whole story.

In this study, we examine "political activists", or politically active citizens, who undertake administrative and advocacy tasks such as campaigning, promoting candidates, attending party meetings, and assisting with party administration, among others. These activists convey crucial information to their fellow citizens, help set the tenor and tone of public campaigns, and can potentially effectively shape public opinion. To the extent that citizen political activism can raise/alter public awareness about politics and politicians, it is natural for politicians to woo activists in order to engender political support from other citizens or from activists themselves. ${ }^{1}$ Further, given the new and emerging evidence regarding the role

\footnotetext{
${ }^{1}$ Examples of such focussed electoral social engineering abound. A recent and relevant one is that of the Bharatiya Janata Party (BJP) in India, which wooed the upper caste voters (specifically the Brahmins) in the 2017 Uttar Pradesh state elections in order to engender larger support because although Brahmins only held 10 percent of the electorate, they frame a disproportionately large share of the public discourse, and their votes were often referred to as the "first vote". "In the local media, at the chai shop, amongst the chattering classes, Brahmins have power to influence the sense of the political hawa" (Vij, 2016).
} 
of information and education in shaping voter preferences (Grossman and Helpman 1996; Wantchekon 2003; Vincente 2014; Banerjee et al, 2011), the potential role of activists as messengers of political information is crucial and begs investigation.

We introduce a model of political clientelism in which a distinction is made between two types of citizen identities: (i) citizens who choose political allegiance when presented with transfers and/or information, and (ii) citizen political activists whose political participation can change the political allegiance of other citizens. Given the opportunity, do politicians opt to make clientelistic transfers to undecided/swing voters to directly influence them, or do they make clientelistic transfers to activists to influence them and their political messages to others? These two distinctive channels of influence through clientelistic transfers are referred to here as the direct and spillover effects, respectively. To explicitly capture the spillover effects, the model innovates by spelling out the interaction between activists and non-activists as a result of a Poisson matching process. This allows us to examine how the political allegiance of non-activists can be shaped by the cumulative effect of all their encounters with activists. In doing so, our model makes the intuitive prediction that if the spillover effect is present, the size of preferential transfers to activists rises with the fraction of politically inactive individuals in a jurisdiction. ${ }^{2}$ In addition to political activism, the model also incorporates a set of other determinants of clientelistic transfers that have received attention in the literature, including income (Dixit and Londregan 1996; Stokes 2005) and party affiliation (Cox and McCubbins 1986).

We offer empirical evidence on this issue in the context of a decentralized public works program, specifically the National Rural Employment Guarantee Scheme (NREGS) in India, arguably one of the largest workfare programs in the developing world. We examine whether village leaders in the southern Indian state of Andhra Pradesh practice clientelism in allocating NREGS jobs and payment based on the household adult male's political affiliation

\footnotetext{
2 There could be other channels of information spillover from activists to other electors. For example, activists may be more influential in remote areas where people has fewer other methods of information communication. We explore more such spillover channels in the empirical model.
} 
and/or activism level. ${ }^{3}$

Our core dataset is from a primary household survey conducted in Andhra Pradesh by the World Bank in August-October 2006, right after the start of NREGS Phase I (February 2006). We focus on villages governed by leaders (henceforth, sarpanch) affiliated with the United Progressive Alliance (UPA), a coalition of parties led by the Indian National Congress (INC). During our study period, the INC held power both at the state-level (Andhra Pradesh) and at the federal-level and accrued much political clout at that time.

We estimate the effects of political affiliation and activism in 2006 on NREGS work and payments received cumulatively in 2006 and 2007 using a Tobit model for UPA-sarpanch villages. The timing of our survey uniquely captures adult male's political affiliation and activism level (which we henceforth call the household's political affiliation and activism) before or around the commencement of the NREGS program. It thus allows us to address the reverse causality problem which concerns most previous studies. We use a rich set of explanatory variables to account for heterogeneity at the household level and use village fixed effects to capture village level unobservable variables from both the supply and the demand sides such as available NREGS projects, weather conditions, and the situation of the rural labor market.

A main identification concern stems from households' self-selection into NREGS works. However, there exists widely reported evidence of administrative rationing and unmet demand for NREGS work especially in the initial years of the program implementation (eg., Ravi and Engler, 2015; Maiorano, 2014). This supply-driven feature of NREGS suggests that the self-selection concern is largely mitigated. To test if this is the case, we use job-card ownership as a proxy for desire to work under NREGS to show that desire to work is not correlated with political affiliation or activism, after controlling for village fixed effects and

\footnotetext{
${ }^{3}$ Andhra Pradesh is interesting for the dichotomy it offers. On the one hand, the state implemented several measures to ensure accountability of the NREGS through real-time availability of data and improved channels for public vigilance and civil society participation (Aiyar and Samji, 2009; Subbarao et al. 2013). On the other hand, the state leads Indian states in terms of the total money seized during elections, a phenomenon particularly acute in local elections (Centre for Media Studies, 2014). It is worthwhile to examine the presence and nature of clientelism within these two parallel worlds.
} 
household observed characteristics. ${ }^{4}$ We also conduct a falsification test using data from non-UPA sarpanch villages to show that our results are not driven by other unobserved demand-side confounding factors. ${ }^{5}$

Although the timing of our survey addresses most reverse causality concerns, some concerns still remain in phase-I villages, where some households may have received benefits or the promise of benefits between program commencement (February 2006) and the survey (August 2006); this could in turn influence their political affiliation and/or activism. ${ }^{6}$ To address this concern, we show that our results remain robust by repeating our analysis after separately dropping households that received NREGS benefits, and dropping households that received a job-card (in response to the promise of benefits) between February 2006 and their interview month. We conduct additional robustness exercises to show that our results are not driven by other concurrent factors such as split of Telangana from Andhra Pradesh and household participation in other public programs. Our results also hold under alternative definitions of political activism and for inclusion of different sets of control variables.

Our results reveal two distinctly striking patterns. First, in villages governed by a UPA-sarpanch, politically active households affiliated to UPA and UPA-rival households obtained significantly higher days of work and payment cumulatively in 2006 and 2007 than politically inactive households in the respective parties. Using insights from our theoretical model, we explore the mechanisms that drive the preferential treatment of political activists, by interacting the binary variable for "political activist" with the share of politically active households within the village. Notably, and consistent with the model with spillover effects, active households living in villages with a larger share of politically inactive households receive more benefits. Furthermore, activists are rewarded with more benefits in remote and

\footnotetext{
${ }^{4}$ Indeed, job-card ownership could be considered a proxy for desire to work because a job-card is the first step in obtaining NREGS benefits; the card is also free of charge and is straightforward to obtain without requiring approvals from upper power echelons. We also show robustness by considering only the job-card-holding households.

${ }^{5}$ Unlike UPA sarpanch, the non-UPA sarpanch lacks the resources and the political will to engage in clientelism (Gupta and Mukhopadhyay, 2016).

${ }^{6}$ This concern does not exist for phase-II villages, in which the NREGS program started after our survey.
} 
less-connected villages where they may play a dominant role as information providers, and in villages with a higher share of households belonging to the same or lower caste as activists in which case they may act as powerful influencers in the caste-based network (Vij, 2016).

Second, inactive households affiliated with the rival party or those unaffiliated with any party are preferentially targeted compared to UPA party loyalists, indicating that the UPA-sarpanch is following an expansionist strategy to increase the party's support base. The scale of overall resources and the extent of clientelistic transfers to political groups in villages dominated by non-UPA households is higher than in villages dominated by UPA households, supporting the expansionist motive of the UPA-sarpanch.

Our paper contributes to the literature in at least two aspects. First, it adds to the theoretical literature on political clientelism by introducing political activism as a key voter characteristic and highlighting information spillover as a channel for activists to be targeted to government programs by politicians. To our knowledge, no previous model has addressed the channel of information spillover through activists in clientelistic transfers. We provide empirical evidence to support the findings of the model. ${ }^{7}$

Second, our result that households affiliated with the rival party or unaffiliated with any party are preferentially targeted provides a stark contrast to other studies in the Indian context which have shown that leaders patronize loyalist households. It also distinguishes from the general literature on clientelistic transfers which suggests either the loyalists or the swing-voters are targeted. Various micro-level studies empirically demonstrate clientelistic transfers in multiple settings, mostly concluding that preferential transfers are offered to political allies or politician households. See Markussen and Tarp (2011) on land improvement investment in Vietnam; Besley, Pande and Rao (2012) and Markussen (2011) on belowpoverty-line (BPL) card in south India; Das (2015) on NREGS jobs and Bardhan et al.

\footnotetext{
${ }^{7}$ Our paper also relates to the literature which studies how politicians target the so-called "political brokers", who are hired because of their deep knowledge of the electoral preferences (Marcolongo 2017; Stokes et al. 2013). In the parlance of this literature, our sarpanch, carrying out the party's wishes of bolstering and expanding the party base, could be considered the broker of the party who is familiar with the village members' preferences and demographics.
} 
(2009) on a host of recurring private benefits in West Bengal. Similar conclusions were drawn concerning fund and resource allocation at the aggregate level (Schady, 2002; Case, 2000; Sheahan et al., 2016; Gupta and Mukhopadhyay, 2016; Dahlberg and Johansson, 2002; Asher and Novosad, 2015; Khemani, 2004; Himanshu et al., 2015; Fried, 2012). ${ }^{8}$

We attribute our distinct finding that the rival-party affiliates are preferentially targeted to three aspects of our study. First, we address critical reverse causality issues, unlike previous studies, which focused on the correlation between party affiliation and program benefits. Second, there is immense diversity in the institutions and the political environment across states in India. The UPA, due to its uniquely powerful position during our study period, may have deployed an expansionist strategy in Andhra Pradesh, unlike other relatively weaker parties which followed a more secure strategy by supporting their own loyalists and securing the party stronghold in other parts of the country other studies are based on. Third, our study in the context of a public works program differs from welfare programs considered in most previous studies. Beneficiaries of public works programs are offered job opportunities, not cash transfers or other "free" benefits like welfare programs. Thus, following an aggressive expansionist strategy to target rival affiliates are probably less offensive to loyalists than typical welfare programs.

Three key aspects of our analysis are worth pointing out here. First, while other public programs also provide potential channels for clientelism, preferential targeting through the NREGS is sizeable and could potentially be dominant because, unlike other programs, NREGS delegates a large amount of resources and discretion to local village leaders. Second, unlike in some prior studies, we do not study clientelistic vote-buying surrounding an election, but instead we study support buying as a practice of decentralized governments,

\footnotetext{
${ }^{8}$ A parallel set of studies shows that firms also benefit from political ties through higher stock market valuations, credit and revenue (Fisman, 2001 (Indonesia); Khwaja and Mian, 2005 (Pakistan); Faccio, 2006 (multi-country); Cingano and Pinotti 2013 (Italy)). Evidence also shows that clientelism operates through the channel of social identity, in which leaders show preference towards their own social group (such as caste, ethnicity, or religion) at the expense of others. This preference takes the form of providing larger targeted transfers to their own group (Burgess et al. 2015; Munshi and Rosenzweig, 2015), focusing on public goods that the leader's group cares about (Banerjee and Somanathan, 2007), or indirectly inhibiting the efficient functioning of public programs that benefit the needy (Anderson et al. 2015).
} 
undermining long-term functioning of democratic politics and development (Bardhan and Mookherjee 2012 and Khemani 2015). Third, our analysis is carried out at the micro-level, rather than at the aggregate level, in order to explicitly capture the role of political activists. Also, micro-studies can potentially offer alternate perspectives to those shown in aggregate-level studies, even within the same context. ${ }^{9}$

The next section introduces the NREGS program both in India as a whole and in Andhra Pradesh. Section 3 describes the theoretical model, while section 4 describes our data and section 5 presents our methodology. We present the results in section 6 and conclude in section 7 .

\section{Andhra Pradesh and the National Rural Employ- ment Guarantee Scheme}

The NREGS was a flagship program of the UPA, a coalition of center-left political parties that governed India for two consecutive five-year terms spanning 2004 to 2009 and 2009 to 2014. During our study period, the UPA held power both at the center and in the state of Andhra Pradesh. In the 2004 state elections in Andhra Pradesh, UPA members included the Indian National Congress (INC), Telangana Rashtra Samithi (TRS), Communist Party of India (CPI), CPI (Marxist), and Majlis-e-Ittehadul Muslimeen (MIM). The non-UPA parties in the 2004 state elections included the Telugu Desam Party (TDP) and the Barathiya Janata Party (BJP). The NREGS obtained constitutional recognition and came into force as a law in September 2005. In 2012-2013, the program generated 2.3 billion person-days of employment for 49.9 million households nationwide, from a budget of US $\$ 47.93$ million. Under this program, adults in rural households can work up to 100 days; this number of

\footnotetext{
${ }^{9}$ This is particularly the case for decentralized programs because local village bodies form the lowest level of governance and the point of contact for potential beneficiary households, the factors influencing such bodies to favor one household over the other under clientelistic programs may differ from those influencing a bureaucrat, for instance, to allocate program funds across different states, districts, or other higher-level governing bodies.
} 
allowable workdays is shared among household's adult individuals.

Panel A in Figure 1 represents various stakeholders and within-state work flows under the NREGS as per federal guidelines. Households first request and obtain a job-card, which forms the basis of identification and is the legal document on which the number of days worked are recorded in order to claim wages. Job-card holders can then seek jobs from the Gram Panchayat (GP), the village-level body headed by the sarpanch, stating the duration for which work is sought. The GP consolidates work requests from households into a shelf of projects. From there, the GP's plan goes up to the block, district, and state levels for evaluation of technical feasibility, fund approval, and fund release. ${ }^{10}$

In the villages of Andhra Pradesh, a state-appointed field assistant (FA) also administers the scheme, in addition to the sarpanch (Panel B in Figure 1). While guidelines suggest that the FA assists the GP secretary in maintaining registers and in measuring work done, in reality, the FA plays a more central role in program implementation (Chamorro et al. 2010). ${ }^{11}$ However, despite the FA's prominence, the sarpanch still has an important stake in the implementation of NREGS - to demonstrate performance and/or to appease constituents - arising from the leader's need to renew the position of power. In fact, since the sarpanch short-lists and assists in choosing the FA (Government of Andhra Pradesh, 2006), the former may potentially control or even ally with the latter. ${ }^{12}$ Particularly, the UPA-sarpanch and the FA are natural partners in action because the FAs are appointed by the state, which

\footnotetext{
${ }^{10}$ Infrastructure projects related to water conservation and water harvesting; drought-proofing, including afforestation; irrigation works; restoration of traditional water bodies; land development; flood control; rural connectivity, and other works notified by the government, are some important works permissible under the scheme's radar. Further, the act sets a minimum limit to the wages to be paid on a time-rate basis or on a piece-rate basis, without gender discrimination. Certain transparency and accountability measures are supposed to be in place, through mechanisms like "squaring of accounts", conducting social audits to ensure accountability through public vigilance and participation of civil society, and maintaining records and ensuring their availability for evaluation and scrutiny.

11 Maiorano (2014) notes that FAs provide job-cards and jobs and decide on the list of projects, all of which are duties of the GP (of which the sarpanch is a member) as per the operational guidelines.

${ }^{12}$ Data from a GP survey show that "for the first and the most recent FA, the village council had the main say in FA appointments in at least 80 per cent of the GPs. In about 40 per cent of appointments, village councils controlled the entire selection process with no mandal level and is therefore well positioned to fudge material expenditures in connivance with other staff (viz., Assistant Engineers, Technical Assistants and/or the suppliers). Hence, the village council and its leader are accountable both for ensuring efficient delivery of program benefits and for the labor and material expenditures on NREGA projects." (Afridi et al. 2017).
} 
is governed by the UPA itself (Maiorano 2014). As per the party's wish, both partners may plausibly work toward achieving the same political objectives - that is, securing or expanding UPA's support base (Afridi et al. 2017).

In what follows, we theoretically model the problem of the local ruling politician (the UPA-sarpanch in our case) who is carrying out the party's goal of bolstering and expanding political support through the tactical distribution of NREGS benefits. Our objective is to extend canonical models of political support to account for voter-level characteristics that may alter the pattern of political clientelism.

\section{A Simple Model of Political Clientelism}

Consider a model of political clientelism with two political parties: the ruling party $(o)$ and the rival party $(r)$. The electorate contains a large number $(N)$ of heterogeneous citizens. Citizen heterogeneity originates from three sources: differences in (i) political preferences $p$, (ii) propensity to participate in political activities $k$, and (iii) income $y .{ }^{13}$ Each citizen, characterized by the triplet $\{p, k, y\}$, chooses a political affiliation $a \in\{o, r, u\}$, to support the ruling party $(o)$, support the rival party $(r)$, or remain unaffiliated $(u)$.

There are three types of political preferences $p \in\{o, r, u\}$, respectively representing proruling party $(o)$, pro-rival party $(r)$, and neutral preferences $(u)$. Let $\theta_{a}^{p}$ denote a parameter that reflects the political preference $p$ of a citizen with party affiliation $a$. We assume that political preference induces an ordering of the choices $a \in\{o, r, u\}$ such that $\theta_{p}^{p}=$ $\max \left\{\theta_{o}^{p}, \theta_{r}^{p}, \theta_{u}^{p}\right\}$, for $p \in\{o, r, u\}$. The fraction of citizens in the electorate with political preference $p$ is given by $\phi^{p} \in(0,1)$, with $\sum_{p=o, r, u} \phi^{p}=1$.

The $N$ citizens embrace different degrees of political activism $k$, which takes on one of two values: $k=\bar{k}>1$ for politically active individuals and $k=1$ otherwise. In our data, politically active individuals are those who participate in political campaigns, attend political

\footnotetext{
${ }^{13}$ In our empirical analysis, we include a vector of socio-economic characteristics in addition to income. These are discussed in detail in Section 4.
} 
meetings, give speeches, write pamphlets, attend political rallies and / or offer donations. We denote $\phi_{\bar{k}}^{o} \geq 0$ and $\phi_{\bar{k}}^{r} \geq 0$ as the share of politically active citizens with party preference $p=o$ and $r$, respectively. The rest of the citizens, $\phi_{1}^{o}=\phi^{o}-\phi_{\bar{k}}^{o}$ and $\phi_{1}^{r}=\phi^{r}-\phi_{\bar{k}}^{r}$, are not politically active $(k=1)$. Citizens with neutral political preferences naturally do not engage in political activities, and thus $\phi_{1}^{u}=\phi^{u}$ and $\phi_{\bar{k}}^{u}=0 .{ }^{14}$

To capture income heterogeneity, we denote $G(y)$ as the cumulative distribution function of income. Across the $N$ citizens, income is independent and identically distributed regardless of party preference and political activism. ${ }^{15}$

The utility of each citizen $\{p, k, y\}$, henceforth $\omega_{k}^{p}(a ; y)$, depends furthermore on that citizen's choice of political affiliation $a$ in the following way:

$$
\omega_{k}^{p}(a ; y)=y+k^{\gamma} \theta_{a}^{p}
$$

where $\gamma \geq 0 .{ }^{16}$

As a benchmark scenario in which politically motivated transfers are absent, it follows directly from (1) that the utility maximizing political affiliation $(a)$ depends only on political preferences $p$, since $\max _{a} \omega_{k}^{p}(a ; y)=\omega_{k}^{p}(p, y), p=\{o, r, u\}$. Thus, the number of citizens who prefer political affiliations $a=o, r$, and $u$ are, respectively, $\phi^{o}, \phi^{r}$ and $\phi^{u}$.

\section{Political Clientelism in a Heterogeneous Citizen Pool}

The ruling politician targets public funds to bolster political support based on the observable characteristics of a citizen prior to any transfers $\{p, k, y\} \cdot{ }^{17}$ We follow the approach of the

\footnotetext{
${ }^{14}$ Thus, political activism is an attribute at the individual level. We are agnostic about the reason individuals differ in $k$, and our specification accommodate situations in which political activism is driven by the intensity of an individuals' political preference, is commissioned by political parties, or both.

${ }^{15}$ It is straightforward to incorporate political preference or political activism specific income distribution. Doing so does not alter the conclusions we report.

16 The parameter $\gamma \geq 0$ captures two potential types of scenarios. When inequality is strict, citizen-cumpolitical activists put greater preference weights on the consequences of their party affiliation choices than inactive individuals. By contrast if $\gamma=0$, citizen utility is independent of political activism. The former is consistent with political activism driven by strong political preferences. The latter is consistent with party commissioned political activities, for example.

${ }^{17}$ From (1), a citizen's political preference is revealed by his/her (observable) choice of political affiliation
} 
long-standing literature starting with Wright (1974), in which targeted transfers are taken to induce a change in a citizen's preference ordering over which party to support. Our model innovates on this previous work by capturing two distinct routes that clientelistic transfers can take.

First, we allow political preferences to vary with the transfers that a citizen receives directly from the politician - we call this the direct effect of targeted transfers. Second, we allow party affiliation preference to vary when politically inactive citizens encounter politically active citizens who are themselves under the influence of targeted transfers from the ruling politician - we call this the spillover effect of targeted transfers. ${ }^{18}$

Denote $b_{k}^{p}(y)$ as the transfer to citizen $\{p, k, y\}$, and $\mathbf{b}_{\bar{k}}^{p}$ as the menu of transfers to politically active citizens with preference $p$ over all income levels $y$. In the context of the NREGS program, these transfers take the form of the total number of days of NREGS employment and the total wage payment received. Because transfers are the products of the ruling politician's flagship program, we assume that only the utility associated with ruling party affiliation is affected by the transfers. Specifically:

$$
\begin{aligned}
\omega_{k}^{p}\left(a ; y, b_{k}^{p}(y)\right)= & y+b_{k}^{p}(y)+k^{\gamma} \theta_{a}^{p}, \text { if } a \neq o \\
= & y+b_{k}^{p}(y)+k^{\gamma} \theta_{o}^{p} \\
& +u_{k}^{p}\left(b_{k}^{p}(y) ; y\right)+I_{k}\left(V^{o}\left(\mathbf{b}_{\bar{k}}^{o}\right)+V^{r}\left(\mathbf{b}_{\bar{k}}^{r}\right)\right)+\epsilon \text {, if } a=o .
\end{aligned}
$$

For all individuals receiving transfers, income increases by $b_{k}^{p}(y)$ to $y+b_{k}^{p}(y)$. We assume that the political affiliation of an individual cannot be contracted conditional on transfers ex ante, ${ }^{19}$ and as such, the preferred party affiliation of citizens will not change subsequent prior to any targeted transfers.

18 Arguably, clientelistic transfers to political activists may affect the tenor and information content of political campaigns. Furthermore, clientelistic transfers may change the intensity of political activities depending on the recipient activist's party affiliation. Our "spillover effect" terminology aims to accommodate the possibility of one or both of these effects of clientelistic transfers to activists.

${ }^{19}$ This assumption can be justified on the grounds that contracts struck due to political clientelism do not receive protection in the court of law and that the timing of transfers particularly in a workfare program are not always in synch with political cycles. 
to transfers, unless political preferences can be influenced by transfers.

In (2), political preference can change due to three reasons: $u_{k}^{p}\left(b_{k}^{p}(y) ; y\right), V^{o}\left(\mathbf{b}_{\bar{k}}^{o}\right)+V^{r}\left(\mathbf{b}_{\bar{k}}^{r}\right)$, and $\epsilon$. Respectively, these refer to the direct effect of transfers, the spillover effect of transfers, and a random preference shifter. Specifically, $\epsilon$ is a uniformly distributed random variable on $[-\bar{\epsilon}, \bar{\epsilon}]$ which reflects any random shifts in the status quo political preference $\left(\theta_{o}^{p}\right)$ occurring due to other exogenous shifts in preferences that are outside of the realm of the ruling politician's influence. ${ }^{20}$ The ruling politician can also play an active role in mobilizing support by directing transfers depending on their direct and spillover effects. We turn to these effects next.

\section{The Direct Effect of Targeted Transfers}

The term $u_{k}^{p}\left(b_{k}^{p}(y), y\right)$ in (2) reflects the direct effect of targeted transfers on the utility associated with ruling party affiliation. In particular, direct transfers mobilize support for the ruling party if and only if $u_{k}^{p}(b)$ is increasing in $b$. The effectiveness of transfers in mobilizing support, $\partial u_{k}^{p} / \partial b$, may be moderated by other citizen-specific characteristics. For example, if political activism implies relative immunity to political support buying (Lindbeck and Weibull 1987), then $\partial u_{k}^{p} / \partial b$ is decreasing in $k$. Furthermore, if a high income status also renders individuals immune to political support buying because of diminishing marginal utility of income (Dixit and Londregan 1996, Stokes 2005), then $\partial u_{k}^{p} / \partial b$ is decreasing in $y$. To capture these potential features of $u_{k}^{p}(b)$ in a tractable way, henceforth we approximate $u_{k}^{p}(\cdot)$ by the following quadratic function:

$$
u_{k}^{p}(b ; y)=\left(\alpha_{b}^{p}+\alpha_{k}^{p} k+\alpha_{y}^{p} y-\alpha_{b b} b / 2\right) b \equiv\left(\alpha^{p}(k, y)-\alpha_{b b} b / 2\right) b
$$

where the sign of $\alpha_{b}^{p}$ shows the direction and strength of the direct effect of transfers, while $\alpha_{k}^{p}$ and $\alpha_{y}^{p}$ show respectively the importance of political activism and income as moderating

\footnotetext{
${ }^{20}$ It is straightforward to extend the model to include ranges of $\epsilon$ that are political preference specific $[-\bar{\epsilon}, \bar{\epsilon}]$. As will be evident in the following sections, doing so does not change any of the qualitative results obtained here.
} 
factors. We assume that $\alpha_{b b}$ is strictly positive to reflect diminishing marginal effectiveness of transfers in eliciting change in political preference.

\section{The Spillover Effect of Targeted Transfers}

To incorporate the spillover effect of clientelistic transfers, which leverages the influence that political activists may have over the political preference of the politically inactive citizens with whom they interact, we denote $I_{k}$ as an indicator variable that takes on the value 1 for politically inactive individuals, and 0 otherwise. The terms $V^{o}\left(\mathbf{b}_{\bar{k}}^{o}\right)$ and $V^{r}\left(\mathbf{b}_{\bar{k}}^{r}\right)$ in $(2)$ reflect the direction and size of the spillover effect.

We assume that the more frequent a politically inactive citizen encounters political activists with political preference $p$, the greater the spillover effect, if any. Thus, let $n^{p}, p=o, r$ denote the number of such encounters. We assume that $n^{o}$ and $n^{r}$ are Poisson distributed random variables, by which the average number of meetings per citizen is given by the population share of the two types of politically active citizens $\phi_{\bar{k}}^{o} / N$ and $\phi_{\bar{k}}^{r} / N$.

The size of the spillover effect furthermore depends on the actual amount of transfers that the political activists receive. Because political activists as a group exhibit different political preferences $(p)$ and a continuum of income levels $(y)$, the size and sign of the spillover effect can potentially differ at each encounter with activists depending on the activists' individual $p$ and $y$. We assume that each one of the $n=0, \ldots, n^{p}$ encounters is a random draw from the distribution of transfers $b_{k}^{p}\left(y_{n}\right)$ received by political activists with preference $p$ and income $y_{n}$. With these motivations in mind, the spillover effect is taken to measure the cumulative influence of the $n^{o}$ and $n^{r}$ number of encounters, respectively, with political activists from the two parties on the political preference of a citizen, $p=o, r$ :

$$
V^{o}\left(\mathbf{b}_{\overline{\mathbf{k}}}^{\mathbf{o}}\right) \equiv \sum_{n=0}^{n^{o}} \beta^{o} b_{\bar{k}}^{o}\left(y_{n}\right), \quad V^{r}\left(\mathbf{b}_{\overline{\mathbf{k}}}^{\mathbf{r}}\right) \equiv \sum_{n=0}^{n^{r}} \beta^{r} b_{\bar{k}}^{r}\left(y_{n}\right) .
$$

where the sign and magnitude of the parameters $\beta^{o}$ and $\beta^{r}$ show the direction and importance 
of the spillover effect through encounters with politically active individuals representing the ruling and rival parties respectively. ${ }^{21}$ A greater transfer to political activists increases support for the ruling politician through the spillover effect if and only if $\beta^{p}$ is positive. At the level of the individual citizen, therefore, the spillover effect is a random variable that depends on citizen-specific realizations of the number of meetings with activists $n^{p}$, the income $y_{n}$ of these activists at each draw $n=0, \ldots, n^{p}$, and thus the transfers that the activists receive $b_{\bar{k}}^{p}\left(y_{n}\right)$

\section{Party Affiliation in the Presence of Targeted Transfers}

Denote $S_{k}^{p}(b, y)$ as the expected fraction of citizens with individuals characteristics $\{p, k, y\}$ and receiving transfers $b$ for whom a political affiliation with the ruling party maximizes utility, where the expectation is taken over all possible income levels $y_{n}$ of politically active citizens, and all possible number of encounters with politically active individuals $n^{p}=0, \ldots, \infty$. Using (2) - (4), it is straightforward to determine that: ${ }^{22}$

$$
S_{k}^{p}(b, y)=s_{k}^{p}+\frac{1}{2 \bar{\epsilon}}\left(\alpha^{p}(k, y)-\alpha_{b b} b / 2\right) b+\frac{I_{k}}{2 \bar{\epsilon}} \sum_{p=o, r} \phi_{\bar{k}}^{p} \beta^{p} \bar{b}_{\bar{k}}^{p} / N
$$

where $\bar{b}_{\bar{k}}^{p}$ denotes the average amount of targeted transfers received by politically active

\footnotetext{
${ }^{21}$ We assume that any effect of political activism, when unadulterated by preferential transfers, is already embodied in the preference parameters $\theta_{o}^{p}$; as such, we assume that $v^{p}(0)=0$.

${ }^{22}$ To see this, note, for example, that a politically inactive rival party citizen receiving transfers $b$ will prefer to affiliate with the ruling party if and only if $\epsilon>\left(\theta_{r}^{r}-\theta_{o}^{r}\right)-\left(\alpha^{p}(1, y)-\alpha_{b b} b / 2\right) b-\sum_{p=o, r} \sum_{n=0}^{n^{p}} \beta^{p} b_{\bar{k}}^{p}$. The associated fraction of individuals who prefer the ruling party is

$$
\frac{1}{2}-\frac{1}{2 \bar{\epsilon}}\left(\left(\alpha^{p}(1, y)+\alpha_{b b} b / 2\right) b+\sum_{p=o, r} \sum_{n=0}^{n^{p}} \beta^{p} b_{\bar{k}}^{p}-\left(\theta_{r}^{r}-\theta_{o}^{r}\right)\right)
$$

Rewrite $\sum_{n=0}^{n^{p}} \beta^{p} b_{\bar{k}\left(y_{n}\right)}^{p}$ as $n^{p} \beta^{p} \sum_{n=0}^{n^{p}} b_{\bar{k}}^{p}\left(y_{n}\right) / n^{p}$. It follows that the fraction of ruling party affiliates in the rival party depends on the random number of encounters with politically active individuals $\left(n^{p}\right)$, and the average transfers these individuals receive $\left(\sum_{n=0}^{n^{p}} b_{\bar{k}}^{p} / n^{p}\right)$. Because the expectation of $n^{p}$ is simply $\phi_{\bar{k}}^{p} / N$ with Poisson arrivals, and sampling among political activists is assumed to be unbiased, the expectation of $\sum_{n=0}^{n^{p}} b_{\bar{k}}^{p} / n^{p}$ is just the population mean, as displayed in (5).
} 
citizens with preference $p$ :

$$
\bar{b}_{\bar{k}}^{p}=\int_{y} b_{\bar{k}}^{p}(y) d G(y) .
$$

$s_{k}^{p}$ is a constant, given by: ${ }^{23}$

$$
s_{k}^{o}=\frac{1}{2}-\frac{k^{\gamma}\left(\max \left\{\theta_{r}^{o}, \theta_{u}^{o}\right\}-\theta_{o}^{o}\right)}{2 \bar{\epsilon}}, \quad s_{k}^{r}=\frac{1}{2}-\frac{k^{\gamma}\left(\theta_{r}^{r}-\theta_{o}^{r}\right)}{2 \bar{\epsilon}},
$$

and

$$
s_{1}^{u}=\frac{1}{2}-\frac{\theta_{u}^{u}-\theta_{o}^{r}}{2 \bar{\epsilon}} .
$$

The two other terms in (5) display the direct and spillover effects of targeted transfers.

\section{Political Clientelism with Citizen Activism}

The ruling politician chooses targeted transfers $b_{k}^{p}(y)$ to citizens with characteristics $p, k$, and $y$ in order to maximize the total citizen support, measured by the aggregate number of ruling party affiliates, accounting for the cost of doing so:

$$
\max _{b_{k}^{p}(y)} \int_{y} \sum_{p=o, r, u} \sum_{k=\bar{k}, 1} \phi_{k}^{p}\left(\rho S_{k}^{p}\left(b_{k}^{p}(y), y\right)-\lambda b_{k}^{p}(y)\right) d G(y),
$$

where $\rho$ reflects the money equivalent gains from a unit increase in aggregate political support, and $\lambda \geq 1$ denotes the marginal cost of public funds. Using (2) - (6), the solution to (7) is given by:

$$
\begin{aligned}
& b_{1}^{p}(y)=\max \left\{\frac{1}{\alpha_{b b}}\left(\alpha^{p}(1, y)-2 \lambda \bar{\epsilon} / \rho\right), 0\right\} \\
& b_{\bar{k}}^{p}(y)=\max \left\{\frac{1}{\alpha_{b b}}\left(\alpha^{p}(\bar{k}, y)-2 \lambda \bar{\epsilon} / \rho+\left(1-\left(\phi_{\bar{k}}^{o}+\phi_{\bar{k}}^{r}\right) / N\right) \beta^{p}\right), 0\right\},
\end{aligned}
$$

where, to recall, $\alpha^{p}(1, y)$ measures the direct effect of transfers to individuals with political

${ }^{23}$ We assume henceforth that interior solutions apply. 
preference $p$, activism $k$ and income $y$ :

$$
\alpha^{p}(k, y)=\alpha_{b}^{p}+\alpha_{k}^{p} k+\alpha_{y}^{p} y
$$

The spillover effect of transfers to political activists with political preference $p$ is

$$
\left(1-\left(\phi_{\bar{k}}^{o}+\phi_{\bar{k}}^{r}\right) / N\right) \beta^{p}
$$

- Naturally, (8) and (9) together admit a range of potential ordering of clientelistic transfers over citizen type $p, k$, and $y$, as proposition 1 illustrates:

Proposition 1 In an interior equilibrium with $b_{k}^{p}(y)>0$, clientelistic transfers

1. to citizens (regardless of political preference and activism) decrease in income $y$ if and only if there is diminishing marginal utility of income $\alpha_{y}^{p}<0$;

2. to non-activists favor rival and neutral affiliates, in that order, $\left(b_{1}^{r}(y)>b_{1}^{u}(y)>b_{1}^{o}(y)\right)$, if and only if the ranking of direct effects is $\alpha^{r}(1, y)>\alpha^{u}(1, y)>\alpha^{o}(1, y)$;

3. to activists over non-activists are positive $b_{\bar{k}}^{p}(y)-b_{1}^{p}(y)>0$ if either $\alpha_{k}^{p}>0$ and $\beta^{p}=0$, or $\alpha_{k}^{p}=0$ and $\beta^{p}>0$, or $\alpha_{k}^{p}<0$ and $\beta^{p}>>0$;

4. to activists over non-activists decrease with the fraction of politically active citizens $\left(\phi_{\bar{k}}^{p}\right)$ in the village if and only if the spillover effect is positive $\left(\beta^{p}>0\right)$.

Let us start with income as a determinant of the direct effect $\alpha^{p}(k, y)$. All else being equal, the ruling politician preferentially targets low-income individuals if and only if $\alpha_{y}^{p}<0$, as in Dixit and Londregan (1996) and Stokes (2005), for example, where the effectiveness of transfers in influencing political preference decreases with the individual's income. Thus, an NREGS program that succeeds in preferentially targeting the poor may in fact have been motivated by political gains in the presence of diminishing marginal utility of income. 
Across individuals with different political preferences, all else being equal, politically inactive citizens with pro-rival and neutral political preferences receive favorable preferential transfers compared to pro-ruling party supporters if and only if,

$$
\alpha_{b}^{p}+\alpha_{k}^{p}+\alpha_{y}^{p} y>\alpha_{b}^{o}+\alpha_{k}^{o}+\alpha_{y}^{o} y, \quad p=r, u
$$

This simply implies that the direct effect of a rupee spent gives rise to a higher increase in the support from rival party citizens, accounting for the moderating effects of political activism and income.

Next, consider political activism as a determinant of clientelistic transfers. From (8) and (9), all else being equal, transfers to activists over non-activists is

$$
b_{\bar{k}}^{p}(y)-b_{1}^{p}(y)=\frac{1}{\alpha_{b b}}\left(\alpha_{k}^{p}(\bar{k}-1)+\left(1-\left(\phi_{\bar{k}}^{o}+\phi_{\bar{k}}^{r}\right) / N\right) \beta^{p}\right) .
$$

It follows that transfers may favor political activists for a combination of reasons. First, contrary to Lindbeck and Weibull (1987), politically active individuals may be more susceptible to the influence of political support buying $\left(\alpha_{k}^{p}>0\right)$. Second, even when political activism has no impact on the direct effect, $\alpha_{k}^{p}=0$, a positive spillover effect, $\beta^{p}>0$, may be present. Third, consistent with Lindbeck and Weibull (1987), politically active individuals may be less susceptible to the direct influence of political support buying $\alpha_{k}^{p}<0$, but the spillover effect may be sufficiently large. To the extent that the signs of both $\beta^{p}$ and $\alpha_{k}^{p}$ are unknown, empirical evidence on the preferential targeting of political activists may imply either that spillover effects are present via $\beta^{p}>0$, or that political activists are relatively susceptible to political support buying via $\alpha_{k}^{p}>0$ as part of the direct effect of targeted transfers to political activists.

To resolve this ambiguity, note from (9) that the magnitude of the spillover effects is inversely related to the share of politically active citizens $\left(\phi_{\bar{k}}^{o}+\phi_{\bar{k}}^{r}\right) / N$, whereas the direct effect is unaffected by this population share. Thus, if spillover effects are indeed present, 
we should expect that such effects are greater in locations where political activism is less common. $^{24}$

We take these implications of the model to the data in the sections that follow. The empirical relationships between clientelistic transfers and citizen characteristics will be taken as evidence of the validity of a number of assumptions about the nature of political preferences, including the existence of direct and spillover effects, and the role of income, political affiliation, and political activism as mediating factors (as stated in Proposition 1).

\section{Data Description}

Our dataset encompasses 1,673 households from villages governed by a UPA affiliated sarpanch in Andhra Pradesh. Our core dataset was collected from a primary field survey conducted between August and October 2006. It spans four districts: Kadapa, Nellore, Warangal, and Nalgonda (the first three belong to phase-I of NREGS implementation, and the last belongs to phase-II). The latter two districts currently belong to Telangana, a state that seceded from Andhra Pradesh in 2014; Kadapa and Nellore are still a part of Andhra Pradesh. ${ }^{25}$

The survey collected job-card numbers for all participating households, enabling us to merge publicly available administrative data (available at http://nrega.ap.gov.in/) into our survey. The administrative data provides information on NREGS workdays and payments for each job card. ${ }^{26}$ Muralidharan, Niehaus, and Sukhtankar (2016) compared NREGS payments from their household survey data with those from the administrative data based on household-reported job card numbers in Andhra Pradesh and did not find any project

\footnotetext{
${ }^{24}$ Across citizens, transfers decrease with the spread of citizens $2 \bar{\epsilon}$, because the same amount of transfers will give rise to a smaller increase in support when $\bar{\epsilon}$ is large. Transfers also decrease in the marginal cost of public funds $\lambda$ and increase in the money equivalent gains of political support $\rho$ as perceived by the ruling politician. All three of these factors are likely to be jurisdiction-specific, which is accounted for in our empirical analysis through village fixed effects.

${ }^{25}$ In section 5, we show that clientelistic patterns are similar across Telangana and non-Telangana district households, implying that the politics of Telangana's secession do not influence our results.

${ }^{26}$ We are able to merge 97 percent of the households who reported to possess job cards with the administrative data based on household-reported job card numbers. The remaining three percent households that we fail to merge with the administrative data are excluded from our final sample.
} 
leakages. ${ }^{27}$ This result is consistent with the results from the verification exercises in Sheahan et al. (2016). ${ }^{28}$ Both studies support that the data we collected yield reliable information on NREGS participation.

Our survey also collected data on household affiliation with a particular political party, if any, which we code into alliances: UPA, UPA-rival, and unaffiliated (the last category implies no affiliation with any party or affiliation with a few fringe parties), based on the coalition definitions stated earlier. ${ }^{29}$ Political affiliation of the village sarpanch is not directly available because elections to the GP do not run on party labels. However, we were able to deduce the sarpanch's party affiliation from households' response to the three questions in our survey: (i) Did you vote for the winner in the last GP election? (ii) If so, was that vote for party affiliation reasons? (iii) With which party are you affiliated?. We found mixed responses regarding the sarpanch's affiliation across households, reflecting that many villagers are unaware of this information about their sarpanch. Considering this heterogeneity in reporting, we assigned each village sarpanch's party affiliation to be the one that more than 50 percent of the sampled households reported. In villages without this majority, we left the affiliation blank. Households stating affiliation with a particular party were also questioned about political activities in which they were involved. We recoded these

${ }^{27}$ Muralidharan, Niehaus, and Sukhtankar (2016) found leakages in NREGS in Andhra Pradesh through two channels: 1. Ghost beneficiaries who did not exist; 2. Fake job cards created by local officials for real households for stealing NREGS money. However in the second case, the households usually do not know about the existence of these job cards. Since our NREGS work data is collected based on the job card numbers reported by the sample households, the information on NREGS participation collected using our method is less subject to these concerns on mismatch and leakages. In fact, Muralidharan, Niehaus, and Sukhtankar (2016) compared NREGS payments between the administrative data and their survey data based on household-reported job cards and did not find any project leakage in subdistricts which formed the control group of their study (which evaluates the Smartcard initiative program in India).

${ }^{28}$ Sheahan et al. (2016), who also used the same administrative dataset as in our paper, verified that the NREGS participation information collected in our way is reliable: "Household interviews on wages earned and work done by job-card holders match entries in post-office or bank books wherever these were available. Likewise individual recall data on the type of work done and number of days are also consistent with administrative data, as are the list of assets created since inception."

29 The same set of questions was administered to females and males in the household, however in our study, we use data reported by males because females tend to participate less in politics, are less politically influential, and make fewer household economic decisions than men. There could be a concern that because party affiliation is self-declared, it may not reflect actual voting behavior but rather a desire to show gratitude to the GP leaders. However, this is not a concern here because the survey was conducted in the interviewee's house by enumerators; and Panchayat leaders are not expected to see the information in the survey. 
activities as either "Politically Active" (campaigning, attending meetings, giving speeches and writing pamphlets, attending rallies, and offering donations), or "Politically Inactive" (No participation).${ }^{30}$

Table 1 provides the distribution of households in our sample based on a variety of characteristics. Over one-third (39.93 percent) of households are UPA-affiliated and politically inactive; 19.25 percent are UPA-affiliated and politically active, 10.64 percent are UPA-rival affiliated and politically inactive, 5.98 percent are UPA-rival affiliated and politically active, and the rest (24.21 percent) are unaffiliated.

The highest representation is by Other Backward Caste (41.06 percent), followed by Scheduled Caste (25.52 percent), Forward Caste (19.90 percent), and Scheduled Tribe (13.51 percent). The "Poorest of the Poor" category represents 36.40 percent of the sample, followed by "Poor" (30.36 percent), "Not so poor" (25.22 percent), and "Non-poor" (8.01 percent) households. ${ }^{31}$

Among household heads, 59.18 percent are not formally literate (they may have received informal education), about a quarter (24.63 percent) received secondary education or below, and about 16.20 percent received high school education. The most popular occupation is casual work in agriculture and other sectors (44.29 percent), followed by salaried work in agriculture and other sectors (30.78 percent) and business ownership or self-employment in agriculture and other sectors (12.25 percent). Non-working adults (typically pensioners/rentiers, dependents, students and those focusing on households chores) form 7.59 percent of the sample; 3.77 percent own common property resources and manage livestock and 1.32 percent are engaged in other occupations. Over three-quarters (77.64 percent) of the

\footnotetext{
${ }^{30}$ We test the robustness of our results to alternative definitions of coding these activities in section 6 .

${ }^{31}$ Household poverty status was determined by a state-wide effort of "participatory identification of the poor" that added vulnerability and social exclusion to quantitative indicators from the 2001 national census and duly ratified by village assemblies. Each household was assigned to one of the four categories: "Poorest of the poor" (those who have food only when they get work, lack shelter, proper clothing, respect, and often cannot send children to school), "Poor" (those who have no land, live on daily wages, and may need to send school-age children to work in times of crisis), "Not so poor" (those who have some land and proper shelter, send children to public schools, and have access to bank credit and public services), and "Non-poor" (those who own at least five acres of land, can hire laborers, send children to private schools, use private hospitals, lend money, and have high status).
} 
sample households have non-literate spouses, 16.98 percent have spouses with secondary education or below (completed grade 10 or below) and 5.38 percent have spouses who have graduated from high school (completed grade 11 or grade 12). The average proportion of adults in a household is about 60 percent and the average hours of newspaper reading per week is 3.97 .

In terms of number of people in each household, 12.97 percent of households have two or fewer members, 15.25 percent have three members, 30.54 percent have four members, and 41.24 percent have five or more members. The majority of farmers (71.55 percent) have less than one acre land, 11.06 percent have between one and two acres of land, 6.28 percent have between two and three acres of land, 5.02 percent have between three and five acres of land, and 6.1 percent have more than five acres of land. Around one-third (33.29 percent) of households dwell in a hamlet. Regarding access to electricity, 16.80 percent of households have no electricity connection, 54.87 percent of households have an electricity connection, and 28.33 percent of households have unofficial electricity connection.

Table 2 describes the cumulative NREGS benefits in 2006 and 2007 in UPA sarpanch villages. Column 1 indicates that UPA-active households obtained the highest proportion of job-cards (42.54 percent), followed by UPA-inactive households (39.37 percent), UPArival active households (38.00 percent), Unaffiliated households (35.30 percent), and UPArival inactive households (31.46 percent). Columns 2 and 3 report averages of days worked and payment received for job-card holders only. Average days worked and payments were highest among UPA-active households (37.03 days and 3,160 Indian Rupees [henceforth, INR]) followed by unaffiliated (35.23 days and 2,672 INR), UPA-inactive (35.11 days and 2,791 INR), UPA-rival inactive (33.33 days and 2,883 INR), and UPA-rival active (23.15 days and 1,911 INR). 


\section{Empirical Methodology}

To empirically examine whether households obtain higher or lower NREGS benefits based on political coalition affiliation and level of political activism, as shown in the theoretical framework, we estimate a Tobit model in which the latent variable is specified as:

$$
y_{i v}=\gamma_{1} \text { PolCategories }_{i v}+\gamma_{2} X_{i v}+\gamma_{v}+\epsilon_{i v}
$$

where $y_{i v}$, the latent variable determined by the above process, in turn yields two observable outcomes for household $i$ at village $v$ : (i) $\log ($ days +1$)$, or the logarithm of days worked in NREGS, and (ii) $\log ($ amount earned+1), or the logarithm of amount earned through NREGS, both cumulative over 2006 and $2007 .{ }^{32} \epsilon_{i v}$ is the error term.

In (11), PolCategories ${ }_{i v}$ is a vector that interacts a household's political affiliation (UPA, UPA-Rival, or unaffiliated) and activism (active or inactive). The interaction gives five political categories: 1) UPA-inactive, 2) UPA-active, 3) UPA-rival Inactive, 4) UPA-rival Active, and 5) Unaffiliated. $X_{i v}$ refers to the following socio-demographic and economic indicators in 2006: caste, poverty status, household size, proportion of adults, primary occupation, education of the household head, education of the spouse, caste, poverty status, land ownership categories, availability of electricity connection, location in a hamlet, and hours spent reading newspapers in the past week. The poverty measure, having been developed from a combination of quantitative and participatory qualitative methods, is unique and precisely captures each household's economic status. We include village fixed effects, $\gamma_{v}$, to capture supply side unobservables (eg., the availability of NREGS jobs and funds at the village level) and demand side factors (eg., rainfall, ratio of land owners versus landless, non-farm opportunities). We cluster standard errors at the village level. The parameter of interest is $\gamma_{1}$, which indicates whether political party membership and activism were considered in the allocation of NREGS work and benefits.

\footnotetext{
32 We set days worked and payments of non-participating households to 0.
} 
There exist several concerns for the identification of the effects of political affiliation and activism in (11). First, households may self-select into the program based on unobserved characteristics (such as desire to work under NREGS) which may be correlated with political affiliation and activism. However, this issue is alleviated largely by the well-documented unmet demand for NREGS work (Gaiha et al. 2010, Dutta et al. 2012, Maiorano 2014, Narayanan and Das 2014, Das 2015, Sheahan et al. 2016, and Sukhtankar 2016). In Andhra Pradesh, the percentage of households that sought but did not receive work was 25 percent in 2009-10 (Liu and Barrett, 2015), and 21 percent, particularly for medak district in 2009 (Ravi and Engler 2015). Rationing was higher in earlier years of the program: 43 percent in 2007 (Ravi and Engler 2015). Narayanan et al. (2016) further argue that the administrative rationing itself may be underestimated because individuals who wish to participate in NREGS may be discouraged from job seeking due to extensive rationing. The supply-driven nature of NREGS is particularly prominent during the initial years of the program (which is our study period), because NREGS wage was almost universally higher than the prevailing rural wage in the initial years of the program.

To test whether the supply-driven feature of NREGS has indeed mitigated the selfselection concern, we use job-card ownership as a proxy for desire to work under NREGS and examine if job-card ownership is correlated with political affiliation and activism in the below Probit specification:

$$
\operatorname{Prob}\left(\text { Jobcard }_{i v}=1\right)=\Phi\left(\eta_{1} \text { PolCategories }_{i v}+\eta_{2} X_{i v}+\eta_{v}+\epsilon_{i v}\right)
$$

where $J_{o b c a r d}$ iv indicates household job-card ownership and $\Phi($.$) is cumulative distribution$ function of the standard normal distribution. All the control variables are the same as in (11). We consider job-card ownership as a good indicator of household's inclination to work in NREGS, because (i) owning a job-card is a prerequisite for NREGS employment; and (ii) job-card issuance in Andhra Pradesh is free of charge and straightforward. We test the null 
hypothesis, $\eta_{1}=0$. We would expect $\eta_{1} \neq 0$ if desire to work is correlated with political affiliation and activism after controlling for the observables. Accordingly, if we fail to reject $\eta_{1}=0$, we are less concerned about this omitted variable issue. In addition, we re-estimate (11) using a restricted sample of only the job-card-holding households to check the robustness of our estimation. We also follow Das (2015) who employs the Heckman selection correction methodology to correct for sample selection bias in the restricted sample. ${ }^{33}$

Second, one may be concerned that other demand-side unobservables at the household level may bias our estimation. For example, activists may be engaged in job seeking more aggressively and, as a result, obtain more NREGS benefits. To deal with this concern, we conduct a falsification test using data from non-UPA sarpanch villages. Our main set of analysis focus on UPA-sarpanch villages. We expect clientelistic transfers of NREGS to be minimal for non-UPA sarpanch villages for three reasons. First, the non-UPA sarpanch lacks the resources for engaging in clientelism and/or is not able to ally with or dominate state-appointed FAs who likely belong to UPA, in order to achieve common political objectives. Second, because the NREGS program was originally conceived by the INC-led UPA government in 2006, there may be "leakage of goodwill" for non-UPA parties to engage in vote/support buying using the NREGS (Gupta and Mukhopadhyay 2016). Finally, nonUPA-sarpanches may not engage in clientelism using NREGS funds because of the rational expectation that electors strongly identify the NREGS with the UPA and may not credit the non-UPA sarpanch with the transfers (Sheahan et al. 2016). ${ }^{34}$ If activists or specific party affiliates are targeted due to unobservable characteristics beyond clientelism, such as their ability to demand for NREGS jobs, significant targeting towards these groups should

\footnotetext{
33 We follow Das (2015) to use the "Proportion of working adults in the household" as the exclusion restriction for the first stage equation of the Heckman model. Das (2015) argues that households with higher number of working members are more likely to seek work but not necessarily be allotted more work, especially after controlling for other socio-demographic characteristics. We use this method to check robustness of our results, having in mind that the exclusion restriction may have limitations.

34 Sheahan et al. (2016) show that sub-district-level NREGS spending before 2008-2009 positively influenced UPA votes in the federal elections of 2009, but did not significantly affect votes for the actual incumbent sub-district leader, hinting that electors perhaps identify the NREGS with the UPA, and credit the UPA for the NREGS benefits they receive even if their leader belongs to a non-UPA party.
} 
be present even in non-UPA sarpanch villages. We test this hypothesis $\left(\gamma_{1}=0\right)$ for $(11)$ in non-UPA sarpanch villages.

Third, reverse causality may arise if party affiliation or activism is a result of benefits received or promised under NREGS. For phase-1 villages (where the program started in February 2006), we measure political affiliation in the survey months of August to October, just after the commencement of NREGS. In phase-2 villages, our survey captures political affiliation before the program started in April 2007, thus making identification cleaner here. However, in phase 1 villages where households in our sample may have received work or promise of work, there is a lapse of six months between when the program started and when we measure political affiliation. Figure 2 presents a timeline of these events. To rule out reverse causality concerns, we conduct a robustness check by repeating the analysis after removing households that received jobs or job-cards (a proxy for seeking work in response to a promise) during these six months.

Fourth, there could be concerns that party affiliation and activism may have been shaped by other program transfers which are correlated with NREGS transfers. We check robustness of our results by controlling for transfers from other village-level public programs, such as the Public Distribution System (PDS) and the Mid-Day Meals (MDM). Our study period is concurrent with the 2004-2010 Telangana protests which sought to separate Telangana districts into a separate state from Andhra Pradesh. There may be a concern that the politics surrounding the secession of Telangana could be driving our results. To alleviate this concern, we interact the binary variable "Residing in a Telangana district" with the political categories to see whether our findings are consistent between Telangana and nonTelangana districts. Since political affiliation and activism are correlated with household socio-economic characteristics which affect NREGS allocation, one may concern that our results may be driven by inclusion or exclusion of certain socio-economic characteristics in the specification. To address this concern, we show robustness of our results while sequentially adding different socio-economic characteristics in the the control. 
In addition, we examine if our empirical results are sensitive to our definition of political activism by redefining the political activism categories as very-active and less-active. In the new definition, only extremely active citizens who are strongly expected to engage in and influence political campaigns and shape public opinion are placed in the very-active group. These activists are individuals involved with campaigning, giving speeches and writing pamphlets. Those citizens engaged in less extreme activities, such as attending rallies, speeches, and meetings, giving donations, or those not involved in any activity were placed in the less-active group..$^{35}$

\section{Results}

In section 6.1, we show how NREGS benefits are targeted based on political activism and affiliation. In section 6.2 , we show results from several falsification tests and robustness checks to support the identification of our empirical strategy. We further explore the underlying mechanisms of the observed clientelistic transfers in section 6.3.

\subsection{Targeting NREGS Benefits based on Political Affiliation and Activism}

Table 3 presents the Tobit regression results of NREGS work days and payments on political affiliation and political activism in UPA-sarpanch villages, from (11). The results indicate that political affiliation and activism play a significant role in explaining NREGS days worked and payments received (columns 1 and 2, respectively). We have two main findings. First, within each of the UPA and UPA-rival groups, activists are targeted significantly more than inactive electors. ${ }^{36}$ Second, among inactive voters, the unaffiliated and rival groups get significantly more benefits than UPA affiliates. Among the active electors, the rival group

\footnotetext{
${ }^{35}$ Only four households offered donations in our sample. Our results are robust when we assign these four households who giving donations to the "very-active" group.

36 The F-test results are reported in Table 3.
} 
gets significantly more than the UPA group. ${ }^{37}$ These results indicate potentially that the UPA-sarpanch is pursuing clientelistic practices in order to elicit support responses from particular target groups outside of his/her party, thus following an expansionist strategy.

The marginal effects on the observed outcomes give a sense of the magnitude of transfers. Compared to the UPA-inactive group, the UPA-sarpanch allocates 21 percent more days and 57 percent more payment to the UPA-active group, 16 percent more days and 34 percent more payment to the UPA-rival inactive group, 40 percent more days and 130 percent more payment to the UPA-rival active group, and 16 percent more days and 35 percent more payment to the unaffiliated group. ${ }^{38}$

Engaging in political clientelism depends crucially on the sarpanch's awareness about the electorate's political preferences, affiliation, and activism levels, which in turn requires strong social networks with village members. Considering the close-knit community that tends to exist in Indian villages, such awareness levels are conceivable. ${ }^{39}$ We relate these findings to the literature on how NREGS played a positive role in UPA's victory in the federal elections in 2009 (Elliott 2011; Ramani 2009; Zimmermann 2015, Sheahan et al. 2016). Although our study does not explicitly examine whether individuals receiving clientelistic transfers voted in favor of UPA in future elections, the findings in this literature strengthen our case by demonstrating that politicians have an incentive to use the NREGS for vote buying if they are rational and aim to maximize votes.

The order of benefits delivered to each political category is different from those presented in the descriptive statistics in Table 2, raising the possibility that the political categories may be correlated with household socio-economic characteristics. To check if our results are sensitive to inclusion/exclusion of certain socio-economics characteristics, we examine in

\footnotetext{
37 Pair-wise F tests between coefficients of the political variables, reported in Table 3, suggest the corresponding differences of the coefficients are statistically significant at the 1 percent level.

38 The marginal effects on log days and log payment are in columns 1 and 2 of Table A1.

39 Typically each village has a large main settlement where the majority of the population lives, and perhaps a few hamlets housing small communities. In our sample, about 83 percent of the sarpanches live in the main settlement, giving them a chance to engage with and learn about the bulk of the village residents' political preferences.
} 
Table A2, the results for days and payment without any control variables (column 1), and after including additional control variables in subsequent regressions (columns 2-8). While column 1 mirrors the descriptive statistics (although all the differences are not significant), the addition of village fixed effects simply changes the results to be consistent with the sarpanch's expansionist strategy and targeting of activists, as seen in Table 3. Addition of control variables does not change the results qualitatively, assuring us that household characteristics do not drive our results. We also present the distribution of the sample by poverty status and caste group for each political category in Table A3, showing that they are not vastly different across political categories.

Despite political affiliation and activism playing important roles, needs-based variables also significantly influence NREGS work and benefits with expected signs. To give a few examples, households whose heads are casual workers (the most vulnerable of the categories), households whose heads and their spouses are not literate and did not receive any formal education, the poorest-of-the-poor households, and households belonging to the historically backward castes receive the most jobs and payments. ${ }^{40}$ Similar results on the importance of need-based variables in public program targeting have also been observed by prior studies. ${ }^{41}$ These results are also consistent with the prediction of our theoretical model which suggests that ruling politician preferentially targets low-income individuals motivated by political gains in the presence of diminishing marginal utility of income (Proposition 1). Our results on clientelism do not implicate the performance of the NREGS in helping the target population, but they are consistent with the larger problems facing decentralization in developing countries (Bardhan and Mookherjee 2012).

\footnotetext{
${ }^{40}$ Scheduled Tribe (ST) households, however, receive less work than Forward Caste households, contrary to expectations of higher needs emerging from this former group (Deshpande, 2001; Srinivasan and Mohanty, 2004). This is perhaps because tribal settlements tend to be isolated, with fewer visiting officers and with rocky soil, making it hard to implement or build infrastructure projects (Maiorano and Buddha, 2014). These attributes of tribal settlements perhaps do not get sufficiently captured by the binary variable indicating "residence in a hamlet".

${ }^{41}$ See, for example, Das (2015) and Sheahan et al. (2016) for coverage of NREGS program in India, and Markussen (2011) and Besley, Pande, Rao $(2005,2012)$ for coverage of Below Poverty Line card provision in India.
} 


\subsection{Falsification Tests and Robustness checks}

To examine if our estimation is biased by household self-selection into NREGS works, we use job-card ownership to proxy for desire to work and run a probit regression of job-card ownership on household characteristics in UPA-sarpanch villages, as in (12). The results are presented in Table 4. The political variables are jointly insignificant at any conventional level. This alleviates our concerns about the missing variable of unobserved desire to work in $(11)$.

Following a different strategy, in Table A4, we restrict our sample to job-card holders only and show that our results on clientelism are consistent (columns 1 and 2). However, these results may suffer a potential sample selection bias. To address this, we employ the Heckman selection correction methodology. Following Das (2015), we use the "Proportion of working adults in the household" as the exclusion restriction for the first stage equation which determines job-card seeking (proxy for desire to work) but not actual work done or payment in the main estimating equation. ${ }^{42}$ This method also yields qualitatively consistent results (columns 3 and 4 of Table A4).

To alleviate the concern that other demand-side unobservables at the household level may have biased our estimation, we conduct a falsification test for (11) using the sample in non-UPA sarpanch villages. ${ }^{43}$ The results are presented in Table 5. The political variables are individually and jointly insignificant for both NREGS workdays and payments, indicating that our findings in UPA-sarpanch villages are not driven by other unobserved demand-side factors (such as activists having higher ability to demand for NREGS work). ${ }^{44}$

To alleviate our concerns of reverse causality, we conduct robustness checks by repeating

\footnotetext{
42 Das (2015) used "number of working adults" as the exclusion restriction, arguing that households with higher number of working members are more likely to seek work but not necessarily be allotted more work, especially after controlling for other socio-demographic characteristics. Our exclusion restriction is comparable to Das (2015) because we also controlled for household size.

43 Table A5 presents the descriptive statistics in non-UPA-sarpanch villages.

44 We conducted similar analysis exclusively for UPA-rival sarpanches (comprising only BJP or TDP party sarpanches) and found no support for clientelism. These results are not presented in this paper but are available upon request.
} 
the analysis in (11) after removing the households that received jobs or job-cards (a proxy for seeking work in response to a promise) during the six months between the commencement of phase-I NREGS (February 2006) and our survey (August-October 2006). Our results remain qualitatively robust after excluding households that received jobs during this period (columns 1 and 2 in Table A6), and alternately excluding households that received a job-card during this period (columns 3 and 4 in Table A6).

Our results are robust after controlling for transfers from the Public Distribution System (columns 1-2 in Table A7) and the Mid-Day Meals (columns 3-4 in Table A7). Further, columns 1-4 in Table A8 present the marginal effects of political categories separately for Telangan and non-Telangana districts. The results remain qualitatively robust across both sets of districts (in comparison with overall marginal effects presented in Table A1), indicating that what we see in Table 3 is not influenced by activities specific to Telangana or non-Telangana movement-driven politics. Our results are also robust to the modified definition of activism (shown in Table A9).

\subsection{Mechanisms}

The empirical results (Table 3) suggest that, in UPA-sarpanch villages (i) politically active households are offered relatively more NREGS jobs and benefits than inactive households; and (ii) Unaffiliated and rival party-affiliated households are preferentially targeted compared to loyalists. In this section, we further explore the underlying mechanisms related to these results.

\subsubsection{Spillover Effects through Activists}

Following the theoretical model, the finding that political active households are targeted may result from two reasons: (i) activists are easily susceptible to transfers $\left(\alpha_{k}^{p}>0\right)$ or (ii) positive spillover effects $\left(\beta^{p}>0\right)$ exist from active to inactive households and the politician expects to tap into those effects. Between these two possible mechanisms, we examine if the 
spillover effects play a major role by testing whether politically active households receive fewer benefits in areas with a higher fraction of politically active citizens (as predicted in Proposition 1). To do this, we interact the share of politically active households in the village $\left(\right.$ Share Active $\left._{v}\right)$ with a binary variable indicating political activism $\left(\right.$ Active $\left._{v i}\right)$ and run the following regression:

$$
y_{i v}=\xi_{1} \text { PolCategories }_{i v}+\xi_{2} \text { Active }_{i v} * \text { ShareActive }_{v}+\xi_{3} X_{i v}+\xi_{v}+\epsilon_{i v}
$$

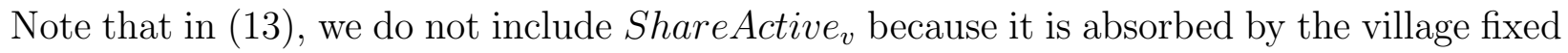
effects and thus cannot be identified. Our parameter of interest is:

$$
\xi_{2}=\left.\frac{\partial E(y)}{\partial \text { ShareActive }}\right|_{\text {Active }=1}
$$

which is predicted to be negative if and only if spillover effects exist and are positive (Proposition 1).

In columns 1 and 2 of Table 6 , we show results from (13) and note that the coefficient estimate of the interaction term of being politically active and the proportion of politically active households is negative and significant at the 1 percent level. Thus, UPA-sarpanches appear to target transfers to political activists, depending on the scale of the influence of political activists in the village. The results imply that a 1 percent increase in the share of politically active households in the population decreases days worked and payments for activists by 0.74 percent and 1.54 percent respectively. This finding is consistent with the prediction of Proposition 1, suggesting that positive spillover effects are the underlying mechanism through which the NREGS benefits are targeted. In other words, our results support that politically active households are targeted in order for them to carry the political goodwill of the ruling party and to influence others.

We next provide supporting results for spillover effects by testing our motivating example in the introduction of this paper, wherein political parties sometimes target brahmins (the 
highest caste group) in India, in order to indirectly influence other voters because brahmins are often looked up to in Indian rural societies (Vij, 2016). We interact the binary variable for activism with the share of households belonging to activists' own- and lower-castes combined as an additional control variable. If the coefficient of this interaction is positive, it indicates that activists are rewarded relatively more benefits if they can influence a larger number of individuals through caste networks, and particularly the lower caste groups by acting as role models. Results from columns 3 and 4 in Table 6 show that the coefficient of the interaction term is indeed positive and significant, which supports the mechanism on information spillover through activists.

Stokes et al. (2013) argue that the usage of middlemen in carrying out party services tends to be stronger in areas where other channels of information spillover are absent and where communication technologies are weaker. To test this, we interact the binary variable for activism and a proxy for availability of communication technology or remoteness of the village and include these separately in our estimating equation. Results from Table 7 show that activists living in remote areas (measured by distance and bus-fare to the nearest town) and those living in areas without telephone connections or fewer telephone lines or those without a community TV are provided relatively more NREGS work days. Similar results are obtained for payments received by households and are presented in Table A10. While these results are not direct predictions from the theoretical model, they provide important supporting evidence for spillover effects from active to inactive voters being an important reason for which activists are targeted.

\subsubsection{Targeting Rival Party Affiliates through an Expansionist Strategy}

Unaffiliated and rival party-affiliated households are preferentially targeted compared to loy-

alists, indicating an expansionist strategy pursued by UPA-sarpanches. If the UPA-sarpanch is indeed engaged in an expansionist strategy to attract rival affiliates, we could expect the extent of clientelism to be higher in villages with a high proportion of non-UPA households. 
To test this, we create a variable at the village level, UPADominance ${ }_{v}$, which takes the value of 1 if a particular village has higher than the median share of UPA households in the sample villages and 0 otherwise. ${ }^{45}$ In a separate regression, we include the interaction of UPADominance ${ }_{v}$ with the political categories: ${ }^{46}$

$$
y_{i v}=\delta_{1} \text { PolCategories }_{i v}+\delta_{2} U \text { PADominance } v \text { PolCategories } \text { Pov }_{i v}+\delta_{3} X_{i v}+\delta_{v}+\epsilon_{i v} .
$$

If the sarpanch follows an expansionist strategy, we expect $\delta_{1}$ and $\delta_{2}$ to have opposite signs so that the absolute value of $\left(\delta_{1}+\delta_{2}\right)$ (the marginal effects of PolCategories $i_{i v}$ on $y_{i v}$ in villages with a higher proportion of UPA households) would be smaller than the absolute value of $\delta_{1}$ (the corresponding marginal effects in villages with a lower proportion of UPA households).

In columns 1 and 2 of Table 8, the coefficients on the interactions of UPA-dominance and political categories are negative and significant at the 1 percent level, indicating that the marginal effects of these political categories on the latent variables for UPA-dominant villages are significantly lower than those for the villages with higher share of non-UPAhouseholds. This finding supports that UPA-sarpanches employ clientelism to expand their party base. In columns 3 and 4 of Table 8, we repeat the analysis in UPA-sarpanch villages with closer political profiles (villages whose share of UPA-affiliated households ranges between 0.25 and 0.75 ), in order for similar villages to be compared with each other. These results are consistent with those in columns 1 and 2.

Our results on the sarpanch favoring rival party-affiliated and unaffiliated households differ from other studies in the Indian context which have found that local leaders patronize loyalists by offering them relatively more benefits. ${ }^{47}$ These differential findings could be

\footnotetext{
45 The median share of UPA households across all vilages is 0.30 .

46 We do not include UPADominance, because it cannot be identified when village fixed effects are included in the regression.

${ }^{47}$ Prior literature on India, as noted in the introduction, found that party loyalists and members are given preference in welfare programs (Das, 2015; Bardhan et al. 2009; Besley, Pande and Rao, 2012; Markussen, 2011.)
} 
explained by our focus on addressing reverse causality issues and by the unique position of power of the INC-led UPA government in Andhra Pradesh, which led the sarpanches to employ such expansionist strategies. Our results are also different from those of Sheahan et al. (2016), which employed sub-district-level data and found no partisan-influenced spending in Andhra Pradesh before the 2009 state assembly election, but a modest role of political leaning in distributing funds after 2009. This contrast strengthens the initial motivation for our work - the fact that within-village household-level benefit allocation patterns could be different from aggregate-level resource allocation patterns.

\subsubsection{Ruling Out Other Mechanisms: Voters and Non-Leader Politicians}

Political activists could be targeted because they are likely to be politicians who are perhaps receiving favors from the village sarpanch. To check if this mechanism holds, in (11), we control for a binary variable indicating whether a politician lives in the household. ${ }^{48}$ Our results do not change after the inclusion of this variable, indicating that this is unlikely a mechanism at play (columns 1 and 2 for days and payments, respectively in Table 9).

Activists or UPA-rival affiliates could be more likely targeted because they may go out and vote more compared to non-activists or UPA affiliates. But this is not a big concern because our data indicate that voting behavior is universal and very similar across the five political categories, and is not particularly high for activists or any party affiliates. ${ }^{49}$ We control for a binary variable on voting in recent elections in (11) and present the results in columns 3 and 4 for days and payment respectively in Table 9. Our results on activists and UPA-rival affiliates being targeted are robust to the inclusion of this variable.

\footnotetext{
48 We define politician here as sarpanch, vice sarpanch, ward member, member of Mandal Parishad Territorial Constituencies, mandal vice-president, mandal president, member of Zilla Parishad Territorial Constituencies, Zilla Parishad vice-chairman, Zilla Parishad chairman, or other political position holder.

49 About 95 percent households voted among the UPA-inactive category; 98 percent voted among the UPA-active category; 93 percent voted among the UPA-rival inactive category; 94 percent voted among the UPA-rival active category; 94 percent voted among the Unaffiliated category. We also run additional regressions to show that political variables are not individually and jointly significantly correlated to voting behavior for UPA-sarpanch villages and non-UPA-sarpanch villages, respectively. These results are available in Table A11.
} 


\section{Conclusion}

This paper contributes to the literature by developing a model of political clientelism based on an under-explored citizen attribute - political activism, in addition to two other attributes: political affiliation and income. The model uncovers the role of "politically active" individuals in their ability to influence and shape opinion, as well as the inclination of politicians to offer targeted transfers to this group in order to indirectly influence other voters (ie., activists or undecided voters).

We take these model predictions to data and examine the clientelistic practices of local village leaders under the National Rural Employment Guarantee Program (NREGS) in India, a public works program operating with unprecedented levels of decentralized funding. We exploit the unique timing of our survey to address critical reverse causality issues in estimating the effects of political affiliation and activism on receiving program benefits. We conduct falsification tests and robustness checks to address identification concerns arising from households' self-selection into NREGS work and other concurrent factors such as split of Telangana from AP and participation of other public programs.

Consistent with the theoretical model, our results provide robust evidence for clientelism in villages governed by a sarpanch affiliated with the UPA coalition; in these villages, the sarpanch is able to strategically allocate more resources to politically active households than to politically inactive households. We show that the active group is targeted because of a potential information spillover from the active to the inactive group, and not particularly because the active group is more susceptible to transfers, or because they tend to be more active job-seekers or earnest voters. We further find that unaffiliated households or rival party affiliates are offered more benefits compared to loyalists, highlighting an expansionist strategy employed by the formidable UPA sarpanch. This collective evidence sheds new light

on clientelistic vote buying through the channels of mobilizing support from swing voters and influencing the behavior of political activists. 


\section{References}

Afridi, Farzana, Vegard Iversen, and M. R. Sharan, "Women Political Leaders, Corruption and Learning: Evidence from a Large Public Program in India," Economic Development and Cultural Change, forthcoming (2017).

Government of Andhra Pradesh, "Andhra Pradesh Employment Guarantee Scheme: Operation Manual," Commissioner, Rural Development, Government of Andhra Pradesh (2006).

Aiyar, Yamini and Salimah Samji, "Transparency and Accountability in NREGA A Case Study of Andhra Pradesh," Accountability Initiative Working paper No. 1, February (2009).

Anderson, Siwan, Patrick Francois, and Ashok Kotwal, "Clientelism in Indian Villages," American Economic Review 105 (2015): 1780-1816.

Asher, Sam and Paul Novosad, "Politics and Local Economic Growth: Evidence from India," Available online at http://www . dartmouth. edu/ novosad/asher-novosad-politicians . $\operatorname{pdf}(2015)$

Bannerjee, Abhijit, Selvan Kumar, Rohini Pande, and Felix Su, "Do Informed Voters Make Better Choices? Experimental Evidence from Urban India," Unpublished working paper (2011).

Banerjee, Abhijit and Rohini Somanathan, "The Political Economy of Public Goods: Some Evidence from India," Journal of Development Economics 82 (2007): 287-314.

Bardhan, Pranab, Sandip Mitra, Dilip Mookherjee and Abhirup Sarkar, "Local Democracy and Clientelism: Implications for Political Stability in Rural West Bengal," Economic \& Political Weekly 44(2009): 46-58.

Bardhan, Pranab and Dilip Mookherjee, "Political Clientelism and Capture Theory and Evidence from West Bengal, India," UNU-WIDER Working Paper No. 2012/97 (2012).

Besley, Timothy, Rohini Pande and Vijayendra Rao, "Participatory Democracy in Action: Survey Evidence from South India," Journal of the European Economic Association 3 (2005): 648-657.

Besley, Timothy, Rohini Pande and Vijayendra Rao, "Just Rewards? Local Politics and Public Resource Allocation in South India," World Bank Economic Review 26 (2012): 191-216. 
Bhattacharyya, Dwaipayan, "Of Control and Factions: The Changing 'Party-Society' in Rural West Bengal," Economic \& Political Weekly 44 (2009): 59-69.

Block, Steven A., "Political Business Cycles, Democratization, and Economic Reform: the Case of Africa," Journal of Development Economics 67 (2009): 205-228.

Case, Anne, "Election Goals and Income Redistribution: Recent Evidence from Albania," European Economic Review 45 (2001): 405-23.

Centre for Media Studies, "Lure of Money in Lieu of Votes in Lok Sabha and Assembly Elections The Trend: 2007-2014," CMS India Corruption Study October (2014).

Chamorro, Mariandrea, Jasmin Cho, Diane Coffey, Dane Erickson, Maria Elena Garcia Mora, Payal Hathi, Jenny Lah, and Piali Mukhopadhyay, "Holding Government to Account: The Case of the National Rural Employment Guarantee Act (NREGA) in Andhra Pradesh, India," Princeton: Princeton University (2010).

Cole, Shawn, "Fixing Market Failures or Fixing Elections? Agricultural Credit in India," American Economic Journal: Applied Economics 1 (2009): 219-50.

Cox, Gary W., and Matthew D. McCubbins, "Electoral Politics as a Redistributive Game," Journal of Politics 48 (1986): 370-389.

Dahlberg, Matz, and Eva Johansson, "On the Vote-Purchasing Behavior of Incumbent Governments," American Political Science Review 96(2002): 27-40.

Das, Upasak, "Does Political Connections and Affiliation Affect Allocation of Benefits in the Rural Employment Guarantee Scheme: Evidence from West Bengal, India," World Development 67 (2015): 202-217.

Dasgupta, Rajarshi, "The CPI(M) Machinery in West Bengal: Two Village Narratives from Koch Bihar and Malda," Economic 83 Political Weekly 44 (2009): 70-81.

Deshpande, Ashwini, "Caste at Birth? Redefining Disparity in India," Review of Development Economics 5 (2001): 130-44.

Dixit, Avinash and John Londregan, "The Determinants of Success of Special Interests in Redistributive Politics," Journal of Politics 58 (1996): 1132-1155.

Dixit, Avinash and John Londregan, "Ideology, Tactics, and Efficiency in Redistributive Politics," Quarterly Journal of Economics 113 (1998): 497-529.

Downs. Anthony, "An Economic Theory of Political Action in a Democracy," Journal of Political Economy 65 (1957): 135-150.

Dutta, Puja, Rinku Murgai, Martin Ravallion, and Dominique van de Walle, "Does India's 
Employment Guarantee Scheme Guarantee Employment?," World Bank Policy Research Discussion Paper 6003 (2012).

Elliott, Carolyn, "Moving from Clientelist Politics Toward a Welfare Regime: Evidence from the 2009 Assembly Election in Andhra Pradesh," Commonwealth and Comparative Politics 49 (2011): 48-79.

Faccio, Mara, "Politically Connected Firms," American Economic Review 96 (2006): 369 386.

Federico Cingano and Paolo Pinotti, "Politicians At Work: The Private Returns And Social Costs Of Political Connections," Journal of the European Economic Association 11 (2013): 433-465.

Finan, Frederico and Laura Schechter, "Vote-Buying and Reciprocity," Econometrica 80 (2012): $863-881$.

Fisman, Raymond, "Estimating the Value of Political Connections," American Economic Review 91 (2001): 1095 - 1102.

Fried, Brian, "Distributive Politics and Conditional Cash Transfers: The Case of Brazil's Bolsa Família," World Development 40 (2011): 1042-1053.

Gaiha, Raghav, Shylashri Shankar and Raghbendra Jha, "Targeting Accuracy of the NREG: Evidence from Rajasthan, Andhra Pradesh and Maharashtra," The Australia South Asia Research Centre (ASARC) Working Paper 2010/03 (2010).

Grossman, Gene M. and Elhanan Helpman, "Electoral Competition and Special Interest Politics," The Review of Economic Studies 63 (1996): 265-286.

Gupta, Bhanu and Abhiroop Mukhopadhyay, "Local Funds and Political Competition: Evidence from the National Rural Employment Guarantee Scheme in India," European Journal of Political Economy 41 (2016): 14-30.

Heckman, James J, "Sample Selection Bias as a Specification Error," Econometrica 47 (1979): 153-161.

Himanshu, Mukhopadhyay, A, and Sharan, M. R, "The National Rural Employment Guarantee Scheme in Rajasthan: Rationed funds and their allocation across villages," Economic and Political Weekly 50 (2015): 52-62.

Johnson, Doug, "How Do Caste, Gender, and Party Affiliation of Locally Elected Leaders Affect Implementation of NREGA?," Working Paper 33. Chennai, India: Centre for Micro Finance at the Institute for Financial Management and Research (2009). 
Khemani, Stuti, "Political Cycles in a Developing Economy: Effect of Elections in the Indian States," Journal of Development Economics 73 (2004): 125-154.

Khemani, Stuti, "Political Capture of Decentralization: Vote-Buying through Grants-Financed Local Jurisdictions," Policy Research Working Paper Series 5350, The World Bank (2010).

Khemani, Stuti, "Buying Votes versus Supplying Public Services: Political Incentives to Under-invest in Pro-poor Policies?," Journal of Development Economics 117 (2015): 84-93.

Khwaja, Asim I., and Atif R. Mian, "Do Lenders Favor Politically Connected Firms? Rent Provision in an Emerging Financial Market," Quarterly Journal of Economics 120 (2005): 1371-1411.

Kitschelt, Herbert, "Linkages between Citizens and Politicians in Democratic Politics," Comparative Political Studies 33 (2000): 845-879.

Kitschelt Herbert and Steven I. Wilkinson, "Citizen-Politician Linkages: An Introduction," In H. Kitchelt, S. Wilkinson (Eds.), Patrons, Clients and Politics: Patterns of Democratic Accountability and Political Competition, Cambridge University Press, Cambridge (2007).

Krueger, Anne O. and Ilter Turan, "The Politics and Economics of Turkish Policy Reform in the 1980s?," In R.Bates and A. Krueger (Eds), Political and Economic Interactions in Economic Policy Reform: Evidence from Eight Countries, Basil Blackwell, Oxford (1993).

Lindbeck, Assar and Jörgen Weibull, "Balanced-budget Redistribution as the Outcome of Political Competition," Public Choice 52 (1987): 273-297.

Maiorano, Diego, "The Politics of the Mahatma Gandhi National Rural Employment Guarantee Act in Andhra Pradesh," World Development 58 (2014): 95-105.

Maiorano, Diego and Chakradhar Buddha "MGNREGA in Andhra Pradesh's Tribal Area," Economics and Political Weekly 49 (2014): 15-17.

Majumdar, Manabi, "Democracy in Praxis: Two Non-Left Gram Panchayats in West Bengal," Economic 83 Political Weekly 44 (2009): 82-93.

Markussen, Thomas, "Inequality and Political Clientelism: Evidence from South India," Journal of Development Studies 47 (2011): 1721-38.

Markussen, Thomas and Finn Tarp, "Political Connections and Investment in Rural Viet- 
nam," WIDER working paper, 2011/37 (2011)

Muralidharan, Karthik, Paul Niehaus, and Sandip Sukhtankar, "Building State Capacity: Evidence from Biometric Smartcards in India," American Economic Review 106 (2016): $2895 ? 2929$.

Moser, Christine, "Poverty Reduction, Patronage, or Vote Buying? The Allocation of Public Goods and the 2001 Election in Madagascar,", Economic Development and Cultural Change 57 (2008): 137-162.

Narayanan, Sudha and Upasak Das, "Women Participation and Rationing in the Employment Guarantee Scheme," Economic and Political Weekly 49 (2014): 46-53.

Narayanan, Sudha, Upasak Das, Yanyan Liu and Christopher Barrett. 2016. "The 'Discouraged Worker Effect' in Public Works Programs: Evidence from the MGNREGA in India," (December 7, 2016). Available at SSRN: https://ssrn.com/abstract=2882149

Ramani, Srinivasan, "A Decisive Mandate,". Economic 83 Political Weekly 44 (2009): 11-12.

Ravi, Shamika and Monica Engler, "Workfare as an Effective Way to Fight Poverty: The Case of India's NREGS," World Development 67 (2015): 57-71.

Remmer, Karen L, "The Political Economy of Elections in Latin America," American Political Science Review 87 (1993): 393-407.

Robinson, James A. and Thierry Verdier, "The Political Economy of Clientelism," The Scandinavian Journal of Economics 115 (2013): 260-291.

Schady, Norbert R, "The Political Economy of Expenditures by the Peruvian Social Fund (FONCODES), 1991-95," American Political Science Review 94 (2000): 289-304

Shi, Min and Jakob Svensson, "Political Budget Cycles: A Review of Recent Developments," Nordic Journal of Political economy 29 (2003): 67-76.

Sheahan,Megan, Yanyan Liu, Christopher B. Barrett, Sudha Narayana, "Preferential Resource Spending under an Employment Guarantee: The Political Economy of NREGS in Andhra Pradesh," World Bank Economic Review DOI: https://doi.org/10.1093/ wber/Ihw044. First published online: August 28, 2016 (2016).

Srinivasan, K., and Sanjay K. Mohanty, "Deprivation of Basic Amenities by Caste and Religion," Economic and Political Weekly 39 (2004): 728-735.

Stokes, Susan, "Perverse Accountability: A Formal Model of Machine Politics with Evidence from Argentina," American Political Science Review 99 (2005): 315-325.

Stokes, Susan, "Political clientelism,". C. Boix, S. Stokes (Eds.), Oxford Handbook of Com- 
parative Politics, Oxford University Press, Oxford (2007).

Stokes, Susan, Thad Dunning, Marcelo Nazareno, and Valeria Brusco, "Brokers, Voters, and Clientelism: The Puzzle of Distributive Politics," Cambridge University Press (2013) Subbarao, Kalanidhi, Carlo del Ninno, Colin Andrews, and Claudia Rodriguez-Alas, "Public Works as a Safety Net - Design, Evidence, and Implementation," Technical Report, World Bank (2013).

Sukhtankar, Sandip, "Sweetening the Deal? Political Connections and Sugar Mills in India," American Economic Journal: Applied Economics 4 (2012): 43-63.

Sukhtankar, Sandip, "India's National Rural Employment Guarantee Scheme: What Do We Really Know about the World's Largest Workfare Program?," India Policy Forum July 12-13, (2016).

Vicente, Pedro C, "Is Vote Buying Effective? Evidence from a Field Experiment in West Africa," Economic Journal 124 (2014): 356-387.

Vij, Shivam, "Why Brahmins Hold The Key To The BJP's Fortunes In Uttar Pradesh," Huffington Post. January 23, 2017. Available online http://www . huffingtonpost.in/ 2016/05/27/up-elections-brahmins_n_10156966.html last accessed on May 21, 2017 (2016).

Wright, Gavin, "The Political Economy of New Deal Spending: An Econometric Analysis," Review of Economics and Statistics 56 (1974): 30-38.

Wyatt, Andre, "Combining Clientelist and Programmatic Politics in Tamil Nadu, South India," Commonwealth \& Comparative Politics 51 (2013): 27-55.

Wantchekon, Leonard, "Clientelism and Voting Behavior: Evidence from a Field Experiment in Benin," World Politics 55 (2003): 399 - 422.

Zimmermann, Laura, "Jai Ho? The Impact of a Large Public Works Program on the Government Election Performance in India," University of Georgia, Athens GA (2015). 
Figure 1: Implementation and Institutional Details of the NREGS

Panel A: Hierarchy and Workflow in the MGNREGS, All-India

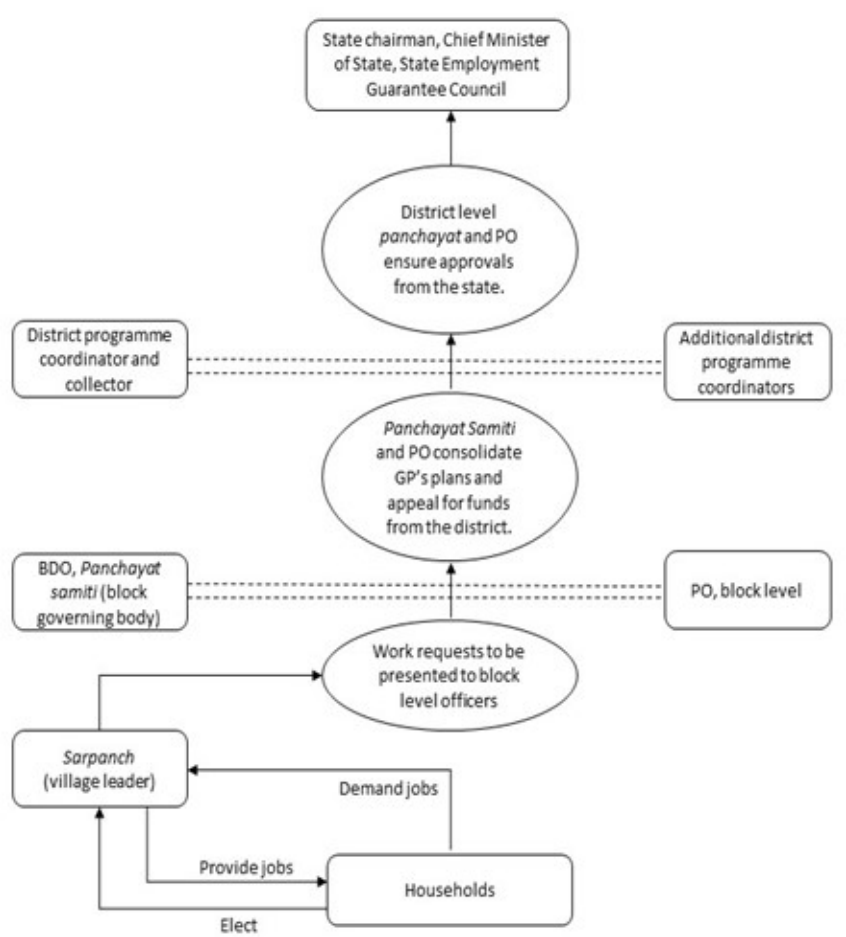

Note: BDO - Block Development Officer; PO - Program Officer; $\mathrm{GP}=$ Gram Panchayat
Panel B: Hierarchy and Workflow in the MGNREGS, Andhra Pradesh

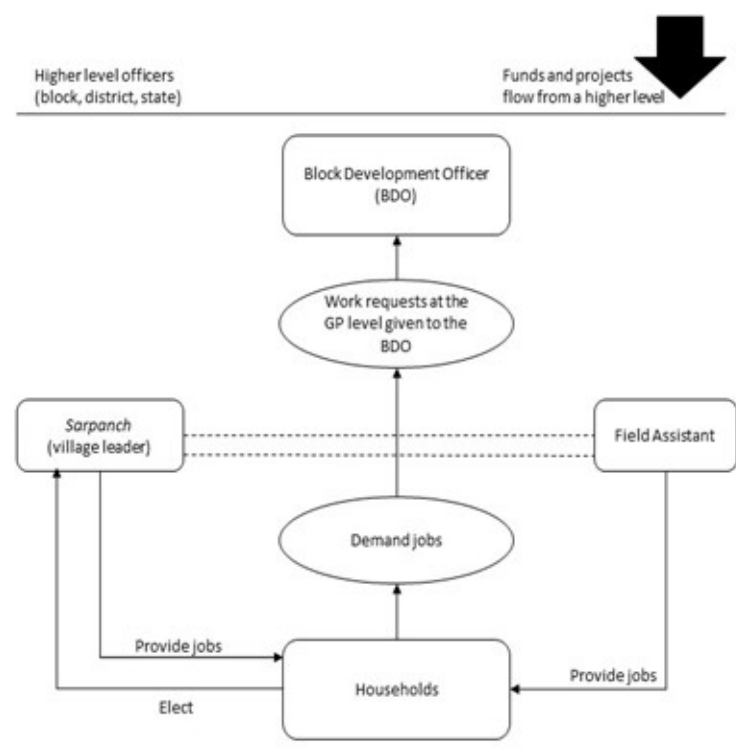

Source: Details sourced from Maiorano (2014); GP=Gram Panchayat 
Figure 2: Timeline of Events
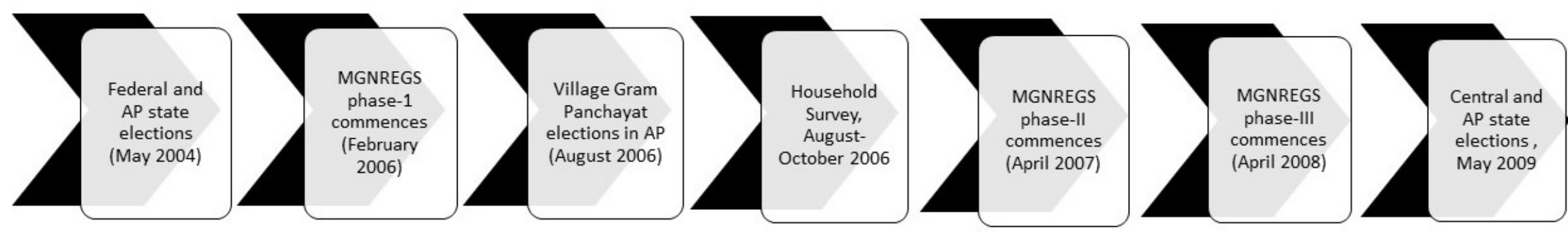

Note: $\mathrm{AP}=$ Andhra Pradesh 
Table 1: Descriptive Statistics

\section{VARIABLES}

Caste

Scheduled Caste

Scheduled Tribe

Other Backward Caste

Forward Caste

Education of the household head

Not literate or received informal education

Secondary education and below

High schoolers and graduates

Primary occupation of the household head

Casual work (Agriculture/others)

Salaried work (Agriculture/others)

Own business or self-employed

Nonworking adults and children, Family

Common property resources, livestock management

Others

\section{Poverty status}

Poorest of the poor

Poor

Not so poor

Not poor

Household political categories

UPA, Politically Inactive

UPA, Politically Active

UPA-Rival, Politically Inactive

UPA-Rival, Politically Active

Unaffiliated

\section{VARIABLES}

Dwelling in a hamlet

Yes

$33.29 \%$

$25.52 \%$

No

$66.71 \%$

$41.06 \%$

$19.90 \%$

Spouse education

Not literate or received informal education $\quad 77.64 \%$

Secondary education and below $\quad 16.98 \%$

$59.18 \% \quad$ High schoolers and graduates $\quad 5.38 \%$

$24.63 \%$

16.20\% Household has electricity connection

Unofficial connection

$28.33 \%$

No

$16.80 \%$

$44.29 \%$

$30.78 \%$

$12.25 \%$

$7.59 \%$

$3.77 \%$

$1.32 \%$

Yes

$54.87 \%$

Household size

$\leq$ two members

$12.97 \%$

Three members

$15.24 \%$

Four members

$30.54 \%$

Five or more members

$41.24 \%$

\section{$36.4 \%$ \\ $30.36 \%$ \\ $25.22 \%$ \\ $8.01 \%$}

$39.93 \%$

$19.25 \%$

$10.64 \%$

$5.98 \%$

$24.21 \%$
Landholdings

$\leq 1$ acre

$71.55 \%$

$>1 \& \leq 2$ acres $\quad 11.06 \%$

$>2 \& \leq 3$ acres $\quad 6.28 \%$

$>3 \& \leq 5$ acres $\quad 5.02 \%$

$>5$ acres $\quad 6.10 \%$

Mean Proportion of adults

$60.00 \%$

Mean Hours of newspaper reading $\quad 3.97$

Sample Size $\quad 1,673$

Number of Villages 261

Note: Politically Active refers to involvement in party activities such as attending rallies, campaigning, attending meetings, giving speeches and writing pamphlets; Politically Inactive households do not participate in political activities. The Unaffiliated category includes those not affiliated with any party or those affiliated with fringe parties that are non-UPA and non-UPA-rival. The involvement level of all unaffiliated households was set to "Politically Inactive". Nonworking adults are pensioners/rentiers, dependents, students and those focusing on households chores. High Schoolers completed grade 11 or 12 . Secondary education and below means completed grade 10 or below. Under each sub-heading in the table, the distribution of households within each category is presented and they sum to $100 \%$, except Mean proportion of adults and Mean hours of newspaper reading which reflects the relevant averages. 
Table 2: Political Categories and NREGS Outcomes in UPA-Sarpanch Villages

\begin{tabular}{llll}
\hline & $(1)$ & $(2)$ & $(3)$ \\
Household Affiliation & $\begin{array}{l}\text { Job-Card } \\
\text { Holding }\end{array}$ & $\begin{array}{l}\text { Mean Days } \\
\text { Worked }\end{array}$ & $\begin{array}{l}\text { Mean } \\
\text { Payment } \\
\text { Received } \\
\text { (INR) }\end{array}$ \\
& & & \\
& & & \multicolumn{2}{c}{ Job-card holders } \\
\hline UPA, Politically Inactive & $39.37 \%$ & 35.11 & 2,791 \\
UPA, Politically Active & $42.54 \%$ & 37.03 & 3,160 \\
UPA-Rival, Politically Inactive & $31.46 \%$ & 33.33 & 2,883 \\
UPA-Rival, Politically Active & $38 \%$ & 23.15 & 1,911 \\
Unaffiliated & $35.30 \%$ & 35.23 & 2,672 \\
All & & \multicolumn{2}{c}{} \\
\hline
\end{tabular}

Note: Politically Active refers to involvement in party activities such as attending rallies, campaigning, attending meetings, giving speeches and writing pamphlets; Politically Inactive households do not participate in political activities. The Unaffiliated category includes those not affiliated with any party or those affiliated with fringe parties that are non-UPA and non-UPA-rival. The involvement level of all unaffiliated households was set to "Politically Inactive". Nonworking adults are pensioners/rentiers, dependents, students and those focusing on households chores. \% Jobcard holding represents the proportion of households that obtained a job-card either in 2006 or 2007. Mean Days worked and Payment Received are averages for each political category based on cumulative benefits received in 2006 and 2007. INR refers to the currency, Indian Rupees. 
Table 3: Tobit Regression of NREGS Benefits on Political Affiliation and Political Activism in UPA-Sarpanch Villages

\begin{tabular}{|c|c|c|c|c|c|}
\hline VARIABLES & $\begin{array}{c}(1) \\
\text { Log Days }\end{array}$ & $\begin{array}{c}(2) \\
\text { Log Payment }\end{array}$ & VARIABLES & $\begin{array}{c}(1) \\
\text { Log Days }\end{array}$ & $\begin{array}{c}(2) \\
\text { Log Payment }\end{array}$ \\
\hline \multicolumn{3}{|l|}{ Household Political Category (base: UPA, Politically Inactive) } & \multicolumn{3}{|l|}{ Electricity connection (base: unofficial connection) } \\
\hline UPA, Politically Active & $\begin{array}{l}0.643^{* * *} \\
(0.0204)\end{array}$ & $\begin{array}{l}1.444^{* * *} \\
(0.0447)\end{array}$ & No connection & $\begin{array}{l}0.0433^{*} \\
(0.0240)\end{array}$ & $\begin{array}{c}0.267^{* * *} \\
(0.0532)\end{array}$ \\
\hline UPA-Rival, Politically Inactive & $\begin{array}{r}0.492^{* * *} \\
(0.0219)\end{array}$ & $\begin{array}{c}0.959^{* * *} \\
(0.0474)\end{array}$ & Official connection & $\begin{array}{c}-1.085^{* * *} \\
(0.0263)\end{array}$ & $\begin{array}{c}-2.473^{* * *} \\
(0.0592)\end{array}$ \\
\hline UPA-Rival Politically Active & $1.054^{* * *}$ & $2.522^{* * *}$ & Number of household members (base: Two or below) & & \\
\hline Unaffiliated & $\begin{array}{l}(0.0290) \\
0.490^{* * *}\end{array}$ & $\begin{array}{l}(0.0637) \\
0.979^{* * *}\end{array}$ & Three members & $\begin{array}{c}0.930 * * * \\
(0.0208)\end{array}$ & $\begin{array}{c}2.010^{* * *} \\
(0.0462)\end{array}$ \\
\hline Occupation of HH head(base:Casual work-Ag/others) & $(0.0155)$ & $(0.0337)$ & Four members & $\begin{array}{l}1.018^{* * *} \\
(0.0232)\end{array}$ & $\begin{array}{l}2.272^{* * *} \\
(0.0519)\end{array}$ \\
\hline Salaried work - Ag/others & $\begin{array}{c}-0.882^{* * *} \\
(0.0278)\end{array}$ & $\begin{array}{c}-1.973^{* * *} \\
(0.0617)\end{array}$ & Five or more members & $\begin{array}{l}0.768^{* * *} \\
(0.0230)\end{array}$ & $\begin{array}{l}1.685^{* * *} \\
(0.0498)\end{array}$ \\
\hline Own business or self-employed & $-0.720^{* * *}$ & $-1.612^{* * *}$ & Landholdings (base: $\leq 1$ acre ) & & \\
\hline Nonworking adults and children, Family & $\begin{array}{l}(0.0398) \\
-1.241^{* * *}\end{array}$ & $\begin{array}{c}(0.0883) \\
-2.725^{* * *}\end{array}$ & $>1 \& \leq 2$ acres & $\begin{array}{c}0.261^{* * *} \\
(0.0184)\end{array}$ & $\begin{array}{c}0.504^{* * *} \\
(0.0407)\end{array}$ \\
\hline Common property resources, livestock management & $\begin{array}{c}(0.0204) \\
-0.971^{* * *}\end{array}$ & $\begin{array}{c}(0.0436) \\
-2.060^{* * *}\end{array}$ & $>2 \& \leq 3$ acres & $\begin{array}{l}0.0603^{*} \\
(0.0318)\end{array}$ & $\begin{array}{c}0.138^{*} \\
(0.0708)\end{array}$ \\
\hline 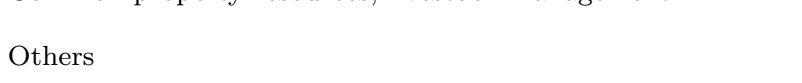 & $\begin{array}{c}(0.0337) \\
-1.647^{* * *}\end{array}$ & $\begin{array}{c}(0.0721) \\
-3.777^{* * *}\end{array}$ & $>3 \& \leq 5$ acres & $\begin{array}{c}-0.756^{* * *} \\
(0.0394)\end{array}$ & $\begin{array}{c}-1.496^{* * *} \\
(0.0883)\end{array}$ \\
\hline Poverty level of HH(base:Poorest of Poor) & $(0.0352)$ & $(0.0760)$ & $>5$ acres & $\begin{array}{c}-0.742^{* * *} \\
(0.0506)\end{array}$ & $\begin{array}{c}-1.335^{* * *} \\
(0.111)\end{array}$ \\
\hline Poor & $-0.210^{* * *}$ & $-0.472^{* * *}$ & & & \\
\hline Not so Poor & $\begin{array}{c}(0.0203) \\
-0.522^{* * *}\end{array}$ & $\begin{array}{c}(0.0449) \\
-1.183^{* * *}\end{array}$ & Proportion of adults & $\begin{array}{c}0.529^{* * *} \\
(0.0186)\end{array}$ & $\begin{array}{c}1.081^{* * *} \\
(0.0407)\end{array}$ \\
\hline Not poor & $\begin{array}{c}(0.0314) \\
-0.767^{* * *}\end{array}$ & $\begin{array}{c}(0.0694) \\
-1.640^{* * *}\end{array}$ & Living in a hamlet & $\begin{array}{c}0.189^{* * *} \\
(0.0118)\end{array}$ & $\begin{array}{c}0.355^{* * *} \\
(0.0263)\end{array}$ \\
\hline Caste (base: Forward Caste) & $(0.0590)$ & $(0.133)$ & Hours newspaper read & $\begin{array}{c}-0.00810^{* * *} \\
(0.00246)\end{array}$ & $\begin{array}{l}-0.00794 \\
(0.00554)\end{array}$ \\
\hline Scheduled Caste & $\begin{array}{c}0.893^{* * *} \\
(0.0233)\end{array}$ & $\begin{array}{c}1.922^{* * *} \\
(0.0519)\end{array}$ & Sigma & $2.813^{* * *}$ & $6.213^{* * *}$ \\
\hline Scheduled Tribe & $\begin{array}{c}-1.254^{* * *} \\
(0.0250)\end{array}$ & $\begin{array}{c}-2.675^{* * *} \\
(0.0553)\end{array}$ & & $(0.00686)$ & $(0.0156)$ \\
\hline Other Backward Caste & $\begin{array}{c}0.548^{* * *} \\
(0.0257)\end{array}$ & $\begin{array}{l}1.308^{* * *} \\
(0.0575)\end{array}$ & $\begin{array}{l}\text { F-test of all political variables } \\
\text { P-value of the F-test }\end{array}$ & $\begin{array}{c}505.02 \\
0.00\end{array}$ & $\begin{array}{c}519.41 \\
0.00\end{array}$ \\
\hline Education of HH head(base:Not-literate/Informal Edu) & & & F-test of $\gamma_{1}^{U P A-\text { rivalactive }}-\gamma_{1}^{U P A-\text { rivalinactive }}$ & 296.06 & 472.68 \\
\hline Secondary and below (completed grade 10 or below) & $\begin{array}{c}0.0369 \\
(0.0226)\end{array}$ & $\begin{array}{c}0.0544 \\
(0.0507)\end{array}$ & $\begin{array}{l}\text { P-value of the F-test } \\
\text { F-test of } \gamma_{1}^{U P A-\text { rivalactive }}-\gamma_{1}^{U P A a c t i v e}\end{array}$ & $\begin{array}{c}0.00 \\
502.21\end{array}$ & $\begin{array}{c}0.00 \\
409.28\end{array}$ \\
\hline Higher secondary and graduate (completed grade 11 or 12 ) & $\begin{array}{c}-0.343^{* * *} \\
(0.0527)\end{array}$ & $\begin{array}{c}-0.843^{* * *} \\
(0.118)\end{array}$ & $\begin{array}{l}\text { F-test of } \gamma_{1}^{0} \\
\text { P-value of the F-test }\end{array}$ & $\begin{array}{c}502.21 \\
0.00\end{array}$ & $\begin{array}{c}409.28 \\
0.00\end{array}$ \\
\hline Education of spouse (base:Not-literate/Informal Edu) & & & Log Pseudo-Likelihood & -1467.2371 & -1842.4879 \\
\hline Secondary and below & $\begin{array}{c}-0.803^{* * *} \\
(0.0384)\end{array}$ & $\begin{array}{c}-1.747^{* * *} \\
(0.0870)\end{array}$ & Pseudo $R^{2}$ & 0.2489 & 0.2078 \\
\hline Higher secondary and graduate & $\begin{array}{c}-0.770^{* * *} \\
(0.0559)\end{array}$ & $\begin{array}{c}-2.027 * * * \\
(0.126)\end{array}$ & Sample Size & 1,673 & 1,673 \\
\hline
\end{tabular}

Note: Robust standard errors clustered at the village level are in parentheses. All regressions include village fixed effects. HH is shortform for household. Politically Active refers to involvement in party activities such as attending rallies, campaigning, attending meetings, giving speeches and writing pamphlets; Politically Inactive households do not participate in political activities. The Unaffiliated category includes those not affiliated with any party or those affiliated with fringe parties that are non-UPA and non-UPA-rival. The involvement level of all unaffiliated households was set to "Politically Inactive". Nonworking adults are pensioners/rentiers, dependents, students and those focusing on households chores. High Schoolers completed grade 11 or 12. Secondary education and below means completed grade 10 or below. The F-test of all political variables has $(4,1675)$ degrees of freedom. F-test of the difference in the coefficient differences has $(1,1675)$ degrees of freedom. 
Table 4: Probit Regression of Job-Card Ownership on Political Affiliation and Political Activism in UPA-Sarpanch Villages

Job card

\begin{tabular}{lc}
\hline Household Political Category (base: UPA, Politically Inactive) \\
\hline UPA, Politically Active & 0.160 \\
& $(0.148)$ \\
UPA-Rival, Politically Inactive & -0.0333 \\
& $(0.156)$ \\
UPA-Rival, Politically Active & 0.322 \\
& $(0.264)$ \\
Unaffiliated & 0.119 \\
& $(0.160)$ \\
Chi-square test of all political variables $\left[\chi^{2}(4)\right]$ & 2.62 \\
P-value of the F-test & 0.6228 \\
Log Pseudo-Likelihood & -634.678 \\
Pseudo $R^{2}$ & 0.2549 \\
& \\
Sample Size & 1,229 \\
\hline
\end{tabular}

Note: Robust standard errors clustered at the village level are in parentheses. All regressions include village fixed effects. Politically Active refers to intense party activities such as attending rallies, campaigning, attending meetings, giving speeches and writing pamphlets; Politically Inactive households do not participate in political activities. The Unaffiliated category includes those not affiliated with any party or those affiliated with fringe parties that are non-UPA and non-UPArival. The involvement level of all unaffiliated households was set to "Politically Inactive". Control variables include caste, poverty status, household size categories, proportion of adults, primary occupation and education of the household head, education of the spouse, land ownership categories, availability of electricity connection, location in a hamlet, and hours spent reading a newspaper in the past week. 
Table 5: Tobit regression of NREGS Benefits on Political Affiliation and Political Activism in non-UPA Sarpanch Villages

\begin{tabular}{lcc}
\hline & $(1)$ & $(2)$ \\
& Log Days & Log Payment \\
\hline Household Political Category & base: UPA-Rival, & Politically Inactive) \\
\hline UPA-Rival, Politically Active & -0.160 & -0.518 \\
& $(0.491)$ & $(1.089)$ \\
UPA, Politically Inactive & 0.649 & 1.052 \\
& $(0.423)$ & $(0.928)$ \\
UPA, Politically Active & 0.595 & 1.175 \\
& $(0.518)$ & $(1.131)$ \\
Unaffiliated & 0.377 & 0.739 \\
& $(0.540)$ & $(1.192)$ \\
Sigma & 2.751 & 5.894 \\
& $(0.203)$ & $(0.379)$ \\
F-test of all political variables & 0.96 & 0.79 \\
P-value of the F-test & 0.4313 & 0.5303 \\
Log Pseudo-Likelihood & -540.5303 & -668.21127 \\
Pseudo $R^{2}$ & 0.2502 & 0.2206 \\
& & 602 \\
Sample Size & 602 & \\
\hline
\end{tabular}

Note: Robust standard errors clustered at the village level are in parentheses. All regressions include village fixed effects. Politically Active refers to intense party activities such as attending rallies, campaigning, attending meetings, giving speeches and writing pamphlets; Politically Inactive households do not participate in political activities. The Unaffiliated category includes those not affiliated with any party or those affiliated with fringe parties that are non-UPA and non-UPA-rival. The involvement level of all unaffiliated households was set to "Politically Inactive". Control variables include caste, poverty status, household size categories, proportion of adults, primary occupation and education of the household head, education of the spouse, land ownership categories, availability of electricity connection, location in a hamlet, and hours spent reading a newspaper in the past week. The F-test of all political variables has $(4,484)$ degrees of freedom. 
Table 6: Testing the Mechanism of Spill-Over Effects from Politically Active to Politically Inactive Group. Tobit Regression results in UPA-Sarpanch Villages

(1)

$(2)$

(3)

(4)

VARIABLES

Log Days Log Payment Log Days

\begin{tabular}{|c|c|c|c|c|}
\hline \multicolumn{5}{|c|}{ Household Political Category (base: UPA, Politically Inactive) } \\
\hline UPA, Politically Active & $\begin{array}{l}1.466^{* * *} \\
(0.0255)\end{array}$ & $\begin{array}{l}3.134^{* * *} \\
(0.0562)\end{array}$ & $\begin{array}{c}0.490^{* * *} \\
(0.0341)\end{array}$ & $\begin{array}{c}0.962^{* * *} \\
(0.0764)\end{array}$ \\
\hline UPA-Rival, Politically Inactive & $\begin{array}{c}0.482^{* * *} \\
(0.0231)\end{array}$ & $\begin{array}{c}0.939^{* * *} \\
(0.0498)\end{array}$ & $\begin{array}{c}0.429^{* * *} \\
(0.0237)\end{array}$ & $\begin{array}{c}0.802 * * * \\
(0.0513)\end{array}$ \\
\hline UPA-Rival, Politically Active & $\begin{array}{c}1.837^{* * *} \\
(0.0309)\end{array}$ & $\begin{array}{c}4.125^{* * *} \\
(0.0685)\end{array}$ & $\begin{array}{c}0.879^{* * *} \\
(0.0399)\end{array}$ & $\begin{array}{c}1.996^{* * *} \\
(0.0901)\end{array}$ \\
\hline Unaffiliated & $\begin{array}{c}0.543^{* * *} \\
(0.0159)\end{array}$ & $\begin{array}{c}1.088^{* * *} \\
(0.0347)\end{array}$ & $\begin{array}{c}0.525^{* * *} \\
(0.0180)\end{array}$ & $\begin{array}{l}1.014^{* * *} \\
(0.0395)\end{array}$ \\
\hline Active X Proportion Active in Village & $\begin{array}{c}-2.406^{* * *} \\
(0.0561)\end{array}$ & $\begin{array}{c}-4.927^{* * * *} \\
(0.123)\end{array}$ & & \\
\hline Share of Own and Lower Caste in Village & & & $\begin{array}{c}-0.571^{* * *} \\
(0.0324)\end{array}$ & $\begin{array}{c}-0.778^{* * *} \\
(0.0724)\end{array}$ \\
\hline Active X Share of Own and Lower Caste in Village & & & $\begin{array}{c}0.372^{* * *} \\
(0.0599)\end{array}$ & $\begin{array}{c}1.017^{* * *} \\
(0.134)\end{array}$ \\
\hline Sigma & $\begin{array}{l}2.809^{* * *} \\
(0.00678)\end{array}$ & $\begin{array}{c}6.206^{* * *} \\
(0.0154)\end{array}$ & $\begin{array}{l}2.785^{* * *} \\
(0.00713)\end{array}$ & $\begin{array}{c}6.168^{* * *} \\
(0.0162)\end{array}$ \\
\hline F-test of all political variables & 1570.18 & 1495.11 & 463.58 & 391.61 \\
\hline P-value of the F-test & 0.00 & 0.00 & 0.00 & 0.00 \\
\hline Log Pseudo-Likelihood & -1466.2456 & -1841.6259 & -1413.4175 & -1777.9171 \\
\hline Pseudo $R^{2}$ & 0.2494 & 0.2081 & 0.2519 & 0.2106 \\
\hline Sample Size & 1,673 & 1,673 & 1,628 & 1,628 \\
\hline
\end{tabular}

Note: Robust standard errors clustered at the village level are in parentheses. All regressions include village fixed effects. Politically Active refers to intense party activities such as attending rallies, campaigning, attending meetings, giving speeches and writing pamphlets; Politically Inactive households do not participate in political activities. The Unaffiliated category includes those not affiliated with any party or those affiliated with fringe parties that are non-UPA and non-UPA-rival. The involvement level of all unaffiliated households was set to "Politically Inactive". Control variables include caste, poverty status, household size categories, proportion of adults, primary occupation and education of the household head, education of the spouse, land ownership categories, availability of electricity connection, location in a hamlet, and hours spent reading a newspaper in the past week. The F-test of all political variables has $(4,1675)$ degrees of freedom for columns 1 and 2 , and $(4,1630)$ degrees of freedom for columns 3 and 4 . 
Table 7: Supporting Results for Spill-Over Effects. Tobit Regression of Log Days on Political Categories and Interaction of Active and Village Connectedness Characteristics

VARIABLES

Household Political Category (base: UPA, Politically Inactive)

UPA, Politically Active

UPA-Rival, Politically Inactive

UPA-Rival, Politically Active

Unaffiliated

$(2)$

$1.064^{* * *}$

$(0.0385)$

Interactions with Village Connectedness Characteristics

Active X Distance to Main Road $0.00969^{* * *}$

Active X Bus Fare to the Nearest Town

(0.00135)

$(0.00309)$

(3)

(0.035*

$\begin{array}{ll}(0.0314) & (0.0329) \\ 0.251^{* * *} & 0.329^{* * *}\end{array}$

$0.613^{* * *}$

$0.491^{* * *}$

$(0.0250)$

$(0.0215)$

$0.484^{* * *} \quad 0.354^{* * *}$

$(0.0283)$

$1.427^{* * *}$

$(0.0229)$

(0.0404)

$\begin{array}{ll}0.561^{* * *} & 0.397^{* * *} \\ (0.0210) & (0.0186)\end{array}$

$1.027^{* * *}$

(0.0257)

$(0.0311)$

$0.484^{* * *}$

$1.388^{* * *}$

(0.0313)

$\begin{array}{ll}0.561^{* * *} & 0.397^{* * *} \\ (0.0210) & (0.0186)\end{array}$

$(0.0161)$

$0.296^{* * *}$

(0.0168)

(5)

(5)

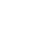

$0.593^{* * *}$

$(0.0283)$

$0.410^{* * *}$

(0.0277)

$1.458^{* * *}$

$(0.0369)$

$0.273^{* * *}$

$(0.0185)$

Active X Non-availability of Community TV

Active X Non-availability of Telephones

Active X Number of Telephone Lines

$0.0751^{*}$

(0.0394)

$2.398^{* * *}$

(0.0370)

$-0.00188^{* * *}$

(0.000219)

Sigma

$2.807^{* * *}$

$2.784^{* * *}$

$2.813^{* * *}$

$2.792^{* * *}$

$2.776^{* * *}$

(0.00888)

(0.00720)

(0.00686)

(0.00721)

(0.00725)

Observations

1,206

1,524

1,537

1,346 
Table 8: Tobit Regression of NREGS Benefits on Political Affiliation and Political Activism, and UPA-Dominance in UPA-Sarpanch Villages

(1)

Log Days
(2)

(3)
(4)

\section{All-villages}

Household Political Category (base: UPA, Politically Inactive)

\section{UPA, Politically Active}

UPA-Rival, Politically Inactive

UPA-Rival, Politically Active

Unaffiliated

UPA, Politically Active X UPA-Dominance

UPA, Politically Inactive X UPA-Dominance

UPA-Rival, Politically Active X UPA-Dominance

Unaffiliated X UPA-Dominance

Sigma

F-test of all political variables:non-UPA-dominant villages

P-value of the F-test

F-test of all political variables:UPA-dominant villages

$\mathrm{P}$-value of the F-test

Log Pseudo-Likelihood

Pseudo $R^{2}$

Sample Size
$2.068^{* * *}$

(0.0489)

$0.958^{* * *}$

(0.0952)

$2.957^{* * *}$

$(0.127)$

$1.588^{* * *}$

(0.0420)

$-1.483^{* * *}$

(0.0517)

$-0.416^{* * *}$

(0.0978)

$-2.062^{* * *}$

(0.136)

$-1.155^{* * *}$

(0.0469)

$2.811^{* * *}$

(0.00669)

3942.55

0.00

1891.94

0.00

$-1466.4789$

0.2493
$3.810^{* * *}$

(0.109)

$1.621^{* * *}$

(0.205)

$6.561^{* * *}$

(0.288)

$3.011^{* * *}$

(0.0915)

$-2.448^{* * *}$

(0.115)

$-0.555^{* * *}$

(0.211)

$-4.417^{* * *}$

(0.308)

$-2.144^{* * *}$

(0.103)

$6.208^{* * *}$

(0.0152)

2865.34

0.00

1216.04

0.00

$-1841.7985$

0.2081
$2.335^{* * *}$

(0.0907)

$1.282^{* * *}$

(0.0896)

$3.323^{* * *}$

(0.148)

$1.654^{* * *}$

(0.0470)

$-1.675^{* * *}$

(0.103)

$-1.370^{* * *}$

(0.0971)

$-2.880^{* * *}$

(0.162)

$-1.368^{* * *}$

(0.0550)

$2.756^{* * *}$

(0.00927)

4015.92

0.0

2356.05

0.0

$-749.7408$

0.2587
$4.285^{* * *}$

(0.202)

$2.208^{* * *}$

(0.192)

$7.440^{* * *}$

(0.335)

$3.054^{* * *}$

(0.102)

$-2.835^{* * *}$

(0.230)

$-2.567^{* * *}$

(0.208)

$-6.442^{* * *}$

(0.367)

$-2.626^{* * *}$

(0.119)

$6.080^{* * *}$

(0.0208)

2958.34

0.0

1768.98

0.0

$-943.28$

0.2187

1,673

1,673

889

889

Note: Robust standard errors clustered at the village level are in parentheses. All regressions include village fixed effects. Politically Active refers to intense party activities such as attending rallies, campaigning, attending meetings, giving speeches and writing pamphlets; Politically Inactive households do not participate in political activities. The Unaffiliated category includes those not affiliated with any party or those affiliated with fringe parties that are non-UPA and non-UPA-rival. The involvement level of all unaffiliated households was set to "Politically Inactive". Control variables include caste, poverty status, household size categories, proportion of adults, primary occupation and education of the household head, education of the spouse, land ownership categories, availability of electricity connection, location in a hamlet, and hours spent reading a newspaper in the past week. The F-test of all political variables has $(4,1675)$ degrees of freedom. UPA-dominant villages take the value 1 if a particular village has higher than the median share of UPA households and 0 otherwise. Villages with close political profiles are those whose share of UPA-affiliated households range between 0.25 and .75 . 
Table 9: Controlling for Additional Political Variables. Marginal Effects from Tobit Regression Results in UPASarpanch Villages

\begin{tabular}{lcccc}
\hline & $(1)$ & $(2)$ & $(3)$ & $(4)$ \\
& Log Days & Log Payment & Log Days & Log Payment \\
\hline \multicolumn{1}{l}{ Household Political Category (base: UPA, Politically Inactive) } & & \\
\multicolumn{1}{l}{ UPA, Politically Active } & $0.162^{* * *}$ & $0.368^{* * *}$ & $0.148^{* * *}$ & $0.339^{* * *}$ \\
& $(0.00734)$ & $(0.0165)$ & $(0.00712)$ & $(0.0160)$ \\
UPA-Rival, Politically Inactive & $0.124^{* * *}$ & $0.243^{* * *}$ & $0.131^{* * *}$ & $0.258^{* * *}$ \\
& $(0.00690)$ & $(0.0146)$ & $(0.00716)$ & $(0.0151)$ \\
UPA-Rival, Politically Active & $0.275^{* * *}$ & $0.672^{* * *}$ & $0.265^{* * *}$ & $0.647^{* * *}$ \\
& $(0.0117)$ & $(0.0275)$ & $(0.0117)$ & $(0.0275)$ \\
Unaffiliated & $0.122^{* * *}$ & $0.246^{* * *}$ & $0.112^{* * *}$ & $0.221^{* * *}$ \\
& $(0.00507)$ & $(0.0108)$ & $(0.00506)$ & $(0.0108)$ \\
Binary for Politician Living in the Household & Yes & Yes & No & No \\
Binary for Household's Adult Male Voting & No & No & Yes & Yes \\
& & & & \\
Sample Size & 1,673 & 1,673 & 1,662 & 1,662 \\
\hline
\end{tabular}

Note: Robust standard errors clustered at the village level are in parentheses. Marginal effects are those on expected censored outcomes. Binary for Household's Adult Male Voting simply indicates if the Adult male of the household voted in the most recent Gram Panchayat election. Binary for Politician Living in the Household indicates if a politician lives in the household. All regressions include village fixed effects. Politically Active refers to intense party activities such as attending rallies, campaigning, attending meetings, giving speeches and writing pamphlets; Politically Inactive households do not participate in political activities. The Unaffiliated category includes those not affiliated with any party or those affiliated with fringe parties that are non-UPA and non-UPA-rival. The involvement level of all unaffiliated households was set to "Politically Inactive". Control variables include caste, poverty status, household size categories, proportion of adults, primary occupation and education of the household head, education of the spouse, land ownership categories, availability of electricity connection, location in a hamlet, and hours spent reading a newspaper in the past week. 


\section{Appendix}

Table A1: Marginal Effects of Political Categories on NREGS Benefits, and their Corresponding Percentage Changes in UPA-Sarpanch Villages

\begin{tabular}{|c|c|c|c|c|}
\hline & $(1)$ & $(2)$ & $(3)$ & $(4)$ \\
\hline & \multicolumn{2}{|c|}{ Marginal Effects } & \multicolumn{2}{|c|}{ Percentage Change } \\
\hline & Log Days & Log Payment & Days & Payment \\
\hline \multicolumn{5}{|c|}{ Household Political Category (base: UPA, Politically Inactive) } \\
\hline UPA, Politically Active & $\begin{array}{l}0.197^{* * *} \\
(0.00994)\end{array}$ & $\begin{array}{c}0.451^{* * *} \\
(0.0226)\end{array}$ & $21.78 \%$ & $57.03 \%$ \\
\hline UPA-Rival, Politically Inactive & $\begin{array}{l}0.148 * * * \\
(0.00899)\end{array}$ & $\begin{array}{c}0.292^{* * *} \\
(0.0190)\end{array}$ & $15.96 \%$ & $33.93 \%$ \\
\hline UPA-Rival, Politically Active & $\begin{array}{c}0.338 * * * \\
(0.0160)\end{array}$ & $\begin{array}{c}0.831^{* * *} \\
(0.0378)\end{array}$ & $40.23 \%$ & $129.72 \%$ \\
\hline Unaffiliated & $\begin{array}{l}0.147^{* * *} \\
(0.00679)\end{array}$ & $\begin{array}{c}0.299 * * * \\
(0.0144)\end{array}$ & $15.84 \%$ & $34.86 \%$ \\
\hline Sample Size & & 1,673 & & \\
\hline
\end{tabular}

Note: Robust standard errors clustered at the village level are in parentheses. Marginal effects are those on expected censored outcomes. Marginal effects and percentages are based on Table 3. 
Table A2: Tobit Regression of Log Days and Payment on Political Categories with and without Control Variables

\begin{tabular}{|c|c|c|c|c|c|c|c|c|}
\hline VARIABLES & $(1)$ & $(2)$ & $(3)$ & $(4)$ & $(5)$ & $(6)$ & $(7)$ & $(8)$ \\
\hline \multicolumn{9}{|c|}{$\begin{array}{l}\text { Dependent Variable: Log Days } \\
\text { Household Political Category (base: UPA, Politically Inactive) }\end{array}$} \\
\hline UPA Politically Active & $\begin{array}{l}-0.124 \\
(0.479)\end{array}$ & $\begin{array}{l}0.124^{* * *} \\
(0.00947)\end{array}$ & $\begin{array}{l}0.322^{*} * * \\
(0.0154)\end{array}$ & $\begin{array}{l}0.246^{* * *} \\
(0.0141)\end{array}$ & $\begin{array}{l}0.393^{* * *} \\
(0.0157)\end{array}$ & $\begin{array}{l}0.317^{* * *} \\
(0.0151)\end{array}$ & $\begin{array}{l}0.352^{* * *} \\
(0.0169)\end{array}$ & $\begin{array}{l}0.643^{* * *} \\
(0.0204)\end{array}$ \\
\hline UPA-Rival, Politically Inactive & $\begin{array}{l}-0.615 \\
(0.525)\end{array}$ & $\begin{array}{l}0.233^{* * *} \\
(0.00886)\end{array}$ & $\begin{array}{l}0.250 * * * \\
(0.0131)\end{array}$ & $\begin{array}{l}0.277^{* * *} \\
(0.0122)\end{array}$ & $\begin{array}{l}0.399^{* * *} \\
(0.0148)\end{array}$ & $\begin{array}{l}0.542^{* * *} \\
(0.0149)\end{array}$ & $\begin{array}{l}0.543^{* * *} \\
(0.0158)\end{array}$ & $\begin{array}{l}0.492^{* * *} \\
(0.0219)\end{array}$ \\
\hline UPA-Rival, Politically Active & $\begin{array}{l}-0.250 \\
(0.683)\end{array}$ & $\begin{array}{l}0.331^{* * *} \\
(0.0114)\end{array}$ & $\begin{array}{l}0.562^{* * *} \\
(0.0164)\end{array}$ & $\begin{array}{l}0.556^{* * *} \\
(0.0156)\end{array}$ & $\begin{array}{l}0.719^{* * *} \\
(0.0185)\end{array}$ & $\begin{array}{l}0.729^{* * *} \\
(0.0172)\end{array}$ & $\begin{array}{l}0.789^{* * *} \\
(0.0213)\end{array}$ & $\begin{array}{l}1.054^{* * *} \\
(0.0290)\end{array}$ \\
\hline Unaffiliated & $\begin{array}{l}-1.701^{* * *} \\
(0.490)\end{array}$ & $\begin{array}{l}0.674^{* * *} \\
(0.00801)\end{array}$ & $\begin{array}{l}0.494^{* * *} \\
(0.0112)\end{array}$ & $\begin{array}{l}0.398^{* * *} \\
(0.0113)\end{array}$ & $\begin{array}{l}0.410^{* * *} \\
(0.0116)\end{array}$ & $\begin{array}{l}0.410^{* * *} \\
(0.0135)\end{array}$ & $\begin{array}{l}0.434^{* * *} \\
(0.0143)\end{array}$ & $\begin{array}{l}0.490^{* * *} \\
(0.0155)\end{array}$ \\
\hline \multicolumn{9}{|c|}{ Dependent Variable: Log Payment } \\
\hline UPA Politically Active & $\begin{array}{l}-0.285 \\
(1.053)\end{array}$ & $\begin{array}{l}0.326^{* * *} \\
(0.0208)\end{array}$ & $\begin{array}{l}0.751^{* * *} \\
(0.0345)\end{array}$ & $\begin{array}{l}0.590^{* * *} \\
(0.0313)\end{array}$ & $\begin{array}{l}0.921^{* * *} \\
(0.0347)\end{array}$ & $\begin{array}{l}0.752^{* * *} \\
(0.0333)\end{array}$ & $\begin{array}{l}0.831^{* * * *} \\
(0.0373)\end{array}$ & $\begin{array}{l}1.444^{* * *} \\
(0.0447)\end{array}$ \\
\hline UPA-Rival, Politically Inactive & $\begin{array}{l}-1.397 \\
(1.147)\end{array}$ & $\begin{array}{l}0.428^{* * *} \\
(0.0193)\end{array}$ & $\begin{array}{l}0.461^{* * *} \\
(0.0287)\end{array}$ & $\begin{array}{l}0.515^{* * *} \\
(0.0267)\end{array}$ & $\begin{array}{l}0.788^{* * *} \\
(0.0318)\end{array}$ & $\begin{array}{l}1.102^{* * *} \\
(0.0317)\end{array}$ & $\begin{array}{l}1.104^{* * *} \\
(0.0337)\end{array}$ & $\begin{array}{l}0.959 * * * \\
(0.0474)\end{array}$ \\
\hline UPA-Rival, Politically Active & $\begin{array}{l}-0.452 \\
(1.503)\end{array}$ & $\begin{array}{l}0.893^{* * *} \\
(0.0251)\end{array}$ & $\begin{array}{l}1.397^{* * *} \\
(0.0364)\end{array}$ & $\begin{array}{l}1.376^{* * *} \\
(0.0347)\end{array}$ & $\begin{array}{l}1.735^{* * *} \\
(0.0408)\end{array}$ & $\begin{array}{l}1.770 * * * \\
(0.0379)\end{array}$ & $\begin{array}{l}1.906^{* * *} \\
(0.0468)\end{array}$ & $\begin{array}{l}2.522^{* * *} \\
(0.0637)\end{array}$ \\
\hline Unaffiliated & $\begin{array}{l}-3.798^{* * *} \\
(1.071)\end{array}$ & $\begin{array}{l}1.379 * * * \\
(0.0175)\end{array}$ & $\begin{array}{l}0.976^{* * *} \\
(0.0246)\end{array}$ & $\begin{array}{l}0.753^{* * *} \\
(0.0251)\end{array}$ & $\begin{array}{l}0.785^{* * *} \\
(0.0254)\end{array}$ & $\begin{array}{l}0.801^{* * *} \\
(0.0296)\end{array}$ & $\begin{array}{l}0.855^{* * *} \\
(0.0310)\end{array}$ & $\begin{array}{l}0.979 * * * \\
(0.0337)\end{array}$ \\
\hline Village Fixed Effects & $\mathrm{NO}$ & YES & YES & YES & YES & YES & YES & YES \\
\hline Poverty Classification & $\mathrm{NO}$ & $\mathrm{NO}$ & YES & YES & YES & YES & YES & YES \\
\hline Caste & $\mathrm{NO}$ & $\mathrm{NO}$ & $\mathrm{NO}$ & YES & YES & YES & YES & YES \\
\hline Dwelling type & $\mathrm{NO}$ & $\mathrm{NO}$ & $\mathrm{NO}$ & $\mathrm{NO}$ & YES & YES & YES & YES \\
\hline Residing in a hamlet & $\mathrm{NO}$ & $\mathrm{NO}$ & $\mathrm{NO}$ & $\mathrm{NO}$ & $\mathrm{NO}$ & YES & YES & YES \\
\hline Education, household head & $\mathrm{NO}$ & $\mathrm{NO}$ & $\mathrm{NO}$ & $\mathrm{NO}$ & $\mathrm{NO}$ & $\mathrm{NO}$ & YES & YES \\
\hline All other controls & $\mathrm{NO}$ & $\mathrm{NO}$ & $\mathrm{NO}$ & $\mathrm{NO}$ & $\mathrm{NO}$ & $\mathrm{NO}$ & $\mathrm{NO}$ & YES \\
\hline Observations & 2,692 & 2,692 & 2,691 & 2,686 & 2,674 & 1,926 & 1,926 & 1,673 \\
\hline
\end{tabular}

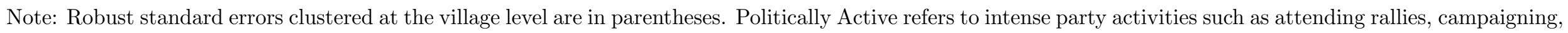

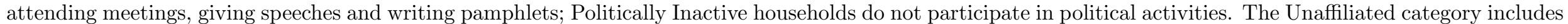

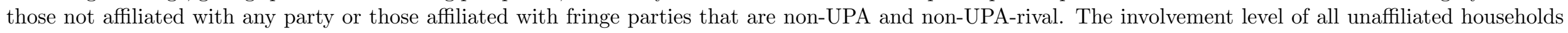

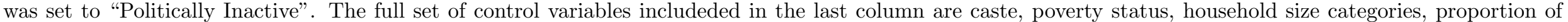

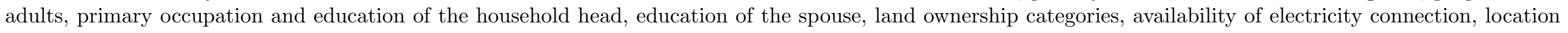
in a hamlet, and hours spent reading a newspaper in the past week. 
Table A3: Political categories by Caste and Povery Characterisitcs

\begin{tabular}{llllll}
\hline VARIABLES & $\begin{array}{l}(1) \\
\text { UPA- } \\
\text { inactive }\end{array}$ & $\begin{array}{l}(2) \\
\text { UPA- } \\
\text { active }\end{array}$ & $\begin{array}{l}(3) \\
\text { UPA-Rival } \\
\text { inactive }\end{array}$ & $\begin{array}{l}(4) \\
\text { UPA Rival } \\
\text { active }\end{array}$ & $\begin{array}{l}(5) \\
\text { Unaffiliated }\end{array}$ \\
\hline $\begin{array}{l}\text { Poverty Categories } \\
\text { Poorest of the Poor }\end{array}$ & $35.38 \%$ & $36.65 \%$ & $36.52 \%$ & $26.73 \%$ & $40.25 \%$ \\
Poor & $30.58 \%$ & $25.47 \%$ & $30.90 \%$ & $33.66 \%$ & $32.84 \%$ \\
Not So Poor & $24.74 \%$ & $30.12 \%$ & $23.03 \%$ & $29.70 \%$ & $22.22 \%$ \\
Not poor & $9.30 \%$ & $7.76 \%$ & $9.55 \%$ & $9.90 \%$ & $4.69 \%$ \\
& & & & & \\
Caste Categories & & & & & \\
Forward caste & $23.54 \%$ & $14.29 \%$ & $20.22 \%$ & $22.77 \%$ & $17.78 \%$ \\
Other Backward caste & $40.78 \%$ & $42.24 \%$ & $44.38 \%$ & $40.59 \%$ & $39.26 \%$ \\
Scheduled Caste & $26.39 \%$ & $27.33 \%$ & $22.47 \%$ & $23.76 \%$ & $24.20 \%$ \\
Scheduled Tribe & $9.30 \%$ & $16.15 \%$ & $12.92 \%$ & $12.87 \%$ & $18.77 \%$ \\
& & & & & \\
Sample Size & 667 & 322 & 178 & 101 & 405 \\
\hline
\end{tabular}


Table A4: Tobit Regression of NREGS Benefits on Political Categories for Participating Households, and the Corresponding Heckman Selection Correction Model in UPA-Sarpanch Villages

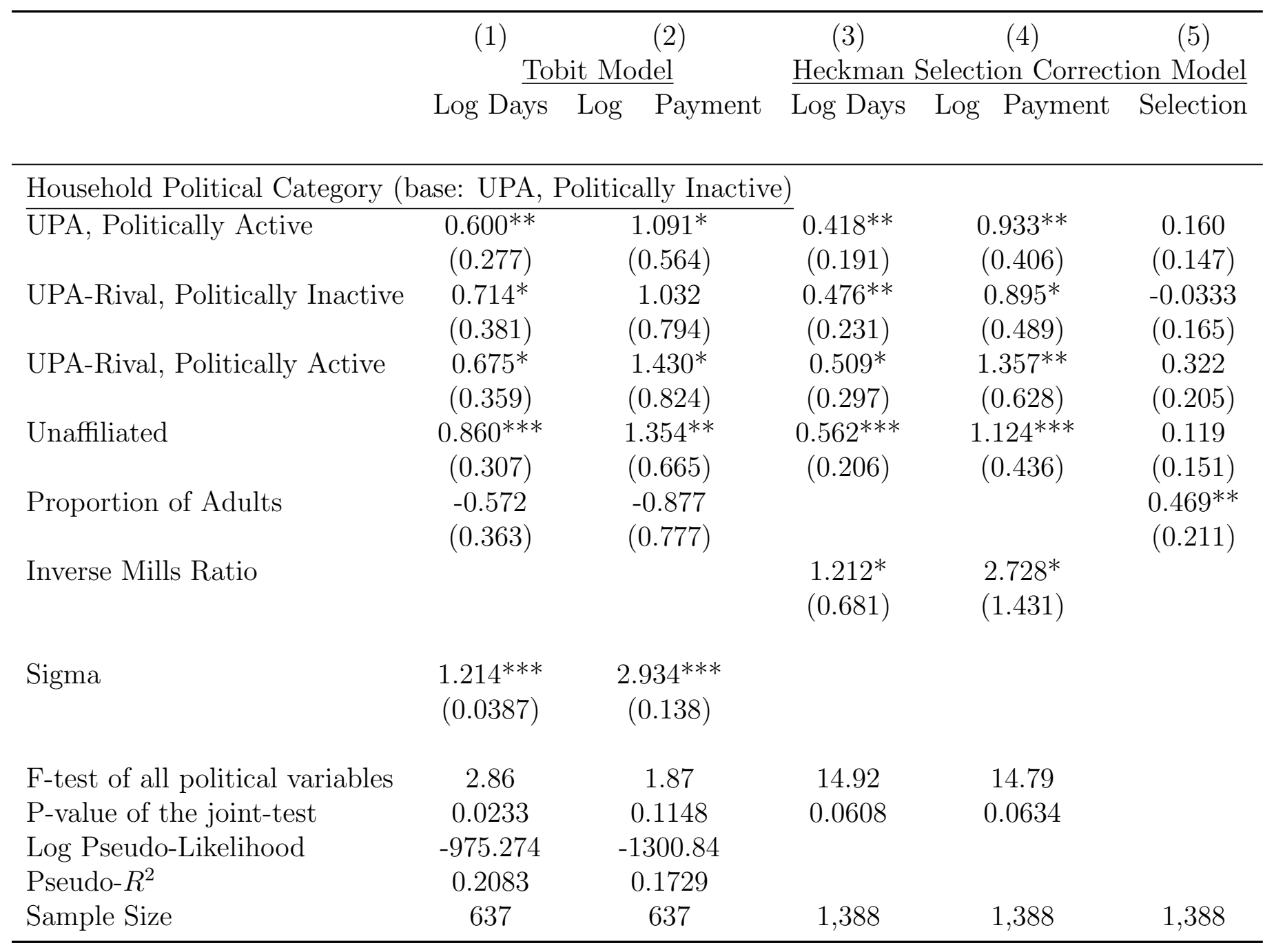

Note: Robust standard errors clustered at the village level are in parentheses. All regressions include village fixed effects. Politically Active refers to intense party activities such as attending rallies, campaigning, attending meetings, giving speeches and writing pamphlets; Politically Inactive households do not participate in political activities. The Unaffiliated category includes those not affiliated with any party or those affiliated with fringe parties that are non-UPA and non-UPA-rival. The involvement level of all unaffiliated households was set to "Politically Inactive". Control variables include caste, poverty status, household size categories, proportion of adults, primary occupation and education of the household head, education of the spouse, land ownership categories, availability of electricity connection, location in a hamlet, and hours spent reading a newspaper in the past week. The joint-test in columns 1 and 2 report F-test results with $(4,418)$ degrees of freedom. Columns 3 and 4 for the joint test report chi-square test results with 8 degrees of freedom. 
Table A5: Descriptive Statistics in non-UPA-Sarpanch Villages

\begin{tabular}{lc}
\hline VARIABLES & $(1)$ \\
\hline Caste & \\
Scheduled Caste & $18.94 \%$ \\
Scheduled Tribe & $19.93 \%$ \\
Other Backward Caste & $17.44 \%$ \\
Forward Caste & $43.69 \%$
\end{tabular}

Education of the household head

Not literate or received informal education $\quad 65.95 \%$

Secondary education and below (completed grade 10 or below) $21.10 \%$

High schoolers and graduates (completed grade 11 or 12 ) $\quad 12.96 \%$

Primary occupation of the household head

Casual work (Agriculture/others)

$40.37 \%$

Salaried work (Agriculture/others)

$35.22 \%$

Own business or self-employed (Agriculture/others) $\quad 9.30 \%$

Nonworking adults $\quad 7.64 \%$

Common property resources, Livestock management $\quad 5.32 \%$

Others

$2.16 \%$

Poverty status

Poorest of the poor $\quad 34.55 \%$

Poor $\quad 32.72 \%$

Not so poor $\quad 24.58 \%$

Not poor $\quad 8.14 \%$

Household political categories

UPA, Politically Inactive $\quad 19.60 \%$

UPA, Politically Active $\quad 10.30 \%$

UPA-Rival, Politically Inactive $\quad 21.43 \%$

UPA-Rival, Politically Active $\quad 14.95 \%$

Unaffiliated $\quad 33.72 \%$

Dwelling in a hamlet

Yes $\quad 31.40 \%$

No $\quad 68.60 \%$

Spouse education

Not literate or received informal education $\quad 79.40 \%$

Secondary education and below (completed grade 10 or below) $16.28 \%$

High schoolers (completed grade 11 or 12) and graduates $4.32 \%$

Continued on next page 
Table A5 - Continued from previous page

\begin{tabular}{lc}
\hline VARIABLES & \\
\hline & \\
Household has electricity connection & 32.39 \\
Unofficial connection & 17.11 \\
No & 50.50 \\
Yes & \\
& \\
Household size & $13.12 \%$ \\
$\leq$ two members & $14.62 \%$ \\
Three members & $27.41 \%$ \\
Four members & $44.85 \%$ \\
Five or more members & \\
& \\
Plot area & $68.60 \%$ \\
$\leq 1$ acre & $11.63 \%$ \\
$>1$ \& $\leq 2$ acres & $6.98 \%$ \\
$>2$ \& 3 acres & $7.31 \%$ \\
$>3$ \& 5 acres & $5.48 \%$ \\
$>5$ acres & \\
& \\
Mean Proportion of adults & $3.34 \%$ \\
Mean Hours of newspaper reading & 602 \\
Sample size & 89 \\
Number of villages &
\end{tabular}

Note: Politically Active refers to involvement in party activities such as attending rallies, campaigning, attending meetings, giving speeches and writing pamphlets; Politically Inactive households do not participate in political activities. The Unaffiliated category includes those not affiliated with any party or those affiliated with fringe parties that are non-UPA and non-UPA-rival. The involvement level of all unaffiliated households was set to "Politically Inactive". Nonworking adults are pensioners/rentiers, dependents, students and those focusing on households chores. Under each sub-heading in the table, the distribution of households within each category is presented and they sum to 100\%, except Mean proportion of adults and Mean hours of newspaper reading which reflects the relevant averages. 
Table A6: Robustness Check, Dropping Households That Got Jobs or Job-Cards Between February 2006 and the Interview Month. Marginal Effects from Tobit Regression Results in UPA-Sarpanch Villages

\begin{tabular}{|c|c|c|c|c|}
\hline & (1) & $(2)$ & (3) & (4) \\
\hline & \multicolumn{2}{|c|}{ Drop Households with Jobs } & \multicolumn{2}{|c|}{ Drop Households with Job-Cards } \\
\hline & Log Days & Log Payment & Log Days & Log Payment \\
\hline \multicolumn{5}{|c|}{ Household Political Category (base: UPA, Politically Inactive) } \\
\hline \multirow{2}{*}{ UPA, Politically Active } & $0.245^{* * *}$ & $0.569^{* * *}$ & $0.0726^{* * *}$ & $0.194^{* * *}$ \\
\hline & $(0.0120)$ & $(0.0282)$ & $(0.00825)$ & $(0.0208)$ \\
\hline \multirow[t]{2}{*}{ UPA-Rival, Politically Inactive } & $0.118^{* * *}$ & $0.262^{* * *}$ & $0.107 * * *$ & $0.259^{* * *}$ \\
\hline & $(0.00876)$ & $(0.0198)$ & $(0.00797)$ & $(0.0190)$ \\
\hline \multirow{2}{*}{ UPA-Rival, Politically Active } & $0.413^{* * *}$ & $0.991^{* * *}$ & $0.170^{* * *}$ & $0.373^{* * *}$ \\
\hline & $(0.0192)$ & $(0.0462)$ & $(0.0166)$ & $(0.0380)$ \\
\hline \multirow{2}{*}{ Unaffiliated } & $0.113^{* * *}$ & $0.253^{* * *}$ & $0.0399 * * *$ & $0.0814^{* * *}$ \\
\hline & $(0.00660)$ & $(0.0150)$ & $(0.00483)$ & $(0.0109)$ \\
\hline Sample Size & 1,549 & 1,549 & 1,258 & 1,258 \\
\hline
\end{tabular}

Note: Robust standard errors clustered at the village level are in parentheses. All regressions include village fixed effects. Politically Active refers to intense party activities such as attending rallies, campaigning, attending meetings, giving speeches and writing pamphlets; Politically Inactive households do not participate in political activities. The Unaffiliated category includes those not affiliated with any party or those affiliated with fringe parties that are non-UPA and non-UPA-rival. The involvement level of all unaffiliated households was set to "Politically Inactive". Control variables include caste, poverty status, household size categories, proportion of adults, primary occupation and education of the household head, education of the spouse, land ownership categories, availability of electricity connection, location in a hamlet, and hours spent reading a newspaper in the past week. The F-test of all political variables in columns 1 and 2 have $(4,1551)$ degrees of freedom, and the those in columns 3 and 4 have $(4,1260)$ degrees of freedom. 
Table A7: Controlling for Other Public Program Transfers. Marginal Effects from Tobit Regression Results in UPA-Sarpanch Villages

\begin{tabular}{|c|c|c|c|c|}
\hline & \multirow{2}{*}{\multicolumn{2}{|c|}{$\begin{array}{l}(1) \\
\text { Log Days }\end{array}$}} & \multirow{2}{*}{\multicolumn{2}{|c|}{$\begin{array}{l}(3) \\
\text { Log Payment }\end{array}$}} \\
\hline & & & & \\
\hline \multicolumn{5}{|c|}{ Household Political Category (base: UPA, Politically Inactive) } \\
\hline UPA, Politically Active & $\begin{array}{l}0.141^{* * *} \\
(0.00729)\end{array}$ & $\begin{array}{l}0.166^{* * *} \\
(0.00738)\end{array}$ & $\begin{array}{c}0.323^{* * * *} \\
(0.0164)\end{array}$ & $\begin{array}{c}0.376^{* * *} \\
(0.0166)\end{array}$ \\
\hline UPA-Rival, Politically Inactive & $\begin{array}{l}0.135^{* * *} \\
(0.00725)\end{array}$ & $\begin{array}{l}0.130^{* * *} \\
(0.00693)\end{array}$ & $\begin{array}{c}0.268^{* * *} \\
(0.0153)\end{array}$ & $\begin{array}{c}0.255^{* * *} \\
(0.0146)\end{array}$ \\
\hline UPA-Rival, Politically Active & $\begin{array}{c}0.271^{* * *} \\
(0.0115)\end{array}$ & $\begin{array}{c}0.277^{* * *} \\
(0.0117)\end{array}$ & $\begin{array}{c}0.664^{* * *} \\
(0.0273)\end{array}$ & $\begin{array}{c}0.675^{* * *} \\
(0.0274)\end{array}$ \\
\hline Unaffiliated & $\begin{array}{l}0.105^{* * *} \\
(0.00487)\end{array}$ & $\begin{array}{l}0.126^{* * *} \\
(0.00535)\end{array}$ & $\begin{array}{c}0.207^{* * *} \\
(0.0104)\end{array}$ & $\begin{array}{c}0.254^{* * *} \\
(0.0114)\end{array}$ \\
\hline Household accessed the PDS & Yes & No & Yes & No \\
\hline Household accessed the MDM & No & Yes & No & Yes \\
\hline Sample Size & 1,666 & 1,673 & 1,666 & 1,673 \\
\hline
\end{tabular}

Note: Robust standard errors clustered at the village level are in parentheses. PDS=Public Distribution System; MDM=Mid-Day Meals program. All regressions include village fixed effects. Politically Active refers to intense party activities such as attending rallies, campaigning, attending meetings, giving speeches and writing pamphlets; Politically Inactive households do not participate in political activities. The Unaffiliated category includes those not affiliated with any party or those affiliated with fringe parties that are non-UPA and non-UPA-rival. The involvement level of all unaffiliated households was set to "Politically Inactive". Control variables include caste, poverty status, household size categories, proportion of adults, primary occupation and education of the household head, education of the spouse, land ownership categories, availability of electricity connection, location in a hamlet, and hours spent reading a newspaper in the past week. 
Table A8: Marginal Effects of NREGS Benefits on Political Affiliation and Political Activism in UPA-Sarpanch villages, by Telangana and non-Telangana Districts

\begin{tabular}{|c|c|c|c|c|}
\hline & (1) & (2) & (3) & (4) \\
\hline & Log Days & $\begin{array}{l}\mathrm{g} \text { Days } \\
\text { non-Telangana }\end{array}$ & $\begin{array}{r}\text { Log } \\
\text { Telangana }\end{array}$ & $\begin{array}{l}\text { Payment } \\
\text { non-Telangana }\end{array}$ \\
\hline \multicolumn{5}{|c|}{ Household Political Category (base: UPA, Politically Inactive) } \\
\hline UPA, Politically Active & $\begin{array}{c}0.162^{* * *} \\
(0.0232)\end{array}$ & $\begin{array}{c}0.151^{* * *} \\
(0.0158)\end{array}$ & $\begin{array}{c}0.354^{* * *} \\
(0.0518)\end{array}$ & $\begin{array}{c}0.351^{* * * *} \\
(0.0353)\end{array}$ \\
\hline UPA-Rival, Politically Inactive & $\begin{array}{c}0.132^{* * *} \\
(0.0354)\end{array}$ & $\begin{array}{c}0.107^{* * *} \\
(0.0228)\end{array}$ & $\begin{array}{l}0.206^{* * *} \\
(0.0740)\end{array}$ & $\begin{array}{c}0.311^{* * *} \\
(0.0497)\end{array}$ \\
\hline UPA-Rival, Politically Active & $\begin{array}{c}0.258^{* * *} \\
(0.0626)\end{array}$ & $\begin{array}{c}0.317^{* * *} \\
(0.0422)\end{array}$ & $\begin{array}{c}0.609^{* * *} \\
(0.144)\end{array}$ & $\begin{array}{c}0.804^{* * *} \\
(0.0966)\end{array}$ \\
\hline Unaffiliated & $\begin{array}{c}0.139^{* * *} \\
(0.0179)\end{array}$ & $\begin{array}{c}0.0885^{* * *} \\
(0.0109)\end{array}$ & $\begin{array}{c}0.262^{* * *} \\
(0.0384)\end{array}$ & $\begin{array}{c}0.212^{* * * *} \\
(0.0235)\end{array}$ \\
\hline Sample Size & 1,673 & 1,673 & 1,673 & 1,673 \\
\hline
\end{tabular}

Note: Robust standard errors clustered at the village level are in parentheses. All regressions include village fixed effects. Politically Active refers to intense party activities such as attending rallies, campaigning, attending meetings, giving speeches and writing pamphlets; Politically Inactive households do not participate in political activities. The Unaffiliated category includes those not affiliated with any party or those affiliated with fringe parties that are non-UPA and non-UPA-rival. The involvement level of all unaffiliated households was set to "Politically Inactive". Control variables include caste, poverty status, household size categories, proportion of adults, primary occupation and education of the household head, education of the spouse, land ownership categories, availability of electricity connection, location in a hamlet, and hours spent reading a newspaper in the past week. 
Table A9: Robustness Check, Redefining Political Categories as Very-active and Less-active. Marginal Effects from Tobit Regression Results in UPA-Sarpanch Villages

Log Days Log Payment

\begin{tabular}{lcc}
\hline Household Political Category (base: UPA, Politically Less Active) \\
\hline UPA, Politically Very Active & $0.0615^{* * *}$ & $0.115^{* * *}$ \\
& $(0.00676)$ & $(0.0149)$ \\
UPA-Rival, Politically Less Active & $0.148^{* * *}$ & $0.332^{* * *}$ \\
& $(0.00871)$ & $(0.0195)$ \\
UPA-Rival, Politically Very Active & $0.469^{* * *}$ & $1.042^{* * *}$ \\
& $(0.0253)$ & $(0.0557)$ \\
Unaffiliated & $0.0828^{* * *}$ & $0.149^{* * *}$ \\
& $(0.00524)$ & $(0.0110)$ \\
Sample Size & & \\
\hline
\end{tabular}

Note: Robust standard errors clustered at the village level are in parentheses. All regressions include village fixed effects. In the alternate definition of political activism used in this regression, Politically Very Active refers to intense party activities such as campaigning, giving speeches and writing pamphlets; Politically Less Active refers to households attending rallies, speeches and meetings, and also not participating in political activities. The Unaffiliated category includes those not affiliated with any party or those affiliated with fringe parties that are non-UPA and non-UPA-rival. The involvement level of all unaffiliated households was set to "Politically Inactive". Control variables include caste, poverty status, household size categories, proportion of adults, primary occupation and education of the household head, education of the spouse, land ownership categories, availability of electricity connection, location in a hamlet, and hours spent reading a newspaper in the past week. The F-test of all political variables has $(4,1675)$ degrees of freedom. 
Table A10: Supporting Results for Spill-Over Effects; Tobit Regression of Log Payment on Political Categories and Interaction of Active and Village Connectedness Characteristics

VARIABLES

Household Political Category (base: UPA, Politically Inactive)

UPA, Politically Active $0.283^{* * *}$

$(0.0695)$

UPA-Rival, Politically Inactive

UPA-Rival, Politically Active

Unaffiliated

(1)

$1.180 * * *$
$0.766^{* * *}$

$(0.0685)$

$2.594^{* * *}$

$(0.0847)$

$(0.0460)$

Interactions with Village Connectedness Characteristics

Active X Distance to main road from village

$0.0176^{* * *}$

$(0.00297)$

Active X Bus fare to the nearest town from village

Active X Non-availability of community TV in village

Active X Non-availability of phone in village

Active X Number of telephone lines in village

Sigma

$6.272^{* * *}$

$(0.0202)$

$6.164^{* * *}$

1,204

Observations

1,522

(2)

$1.322^{* * *}$

$1.136^{* * *}$

$0.919^{* * *}$

$1.172^{* * *}$

(0.0711)

(0.0549)

(0.0470)

(0.0613)

$0.898^{* * *}$

$0.935^{* * *}$

$0.416^{* * *}$

0.530 ***

(0.0603)

$3.543 * * *$

$(0.0495)$

$2.253^{* * *}$

$(0.0561)$

$3.135^{* * *}$

$(0.0601)$

(0.0882)

$0.873^{* * *}$

$(0.0681)$

$0.941^{* * *}$

(0.0692)

$0.474^{* * *}$

$3.323^{* * *}$

(0.0814)

(0.0406)

(0.0349)

(0.0365)

$0.411^{* * *}$

(0.0397)
(0.0163)

$-0.003$

(0.00694)

$0.788^{* * *}$

(0.0868)

$5.427^{* * *}$

(0.0813)

$-0.0046^{* * *}$

(0.000487)

$6.210 * * *$

(0.0156)

$6.163^{* * *}$

$6.091^{* * *}$

(0.0166)

(0.0166)

(

\begin{abstract}
1,673
\end{abstract}
1,529

1,339 
Table A11: Ordinary Least Squares Regression of Voting Behavior on Political Affiliation and Political Activism

\begin{tabular}{lcc}
\hline & $(1)$ & $(2)$ \\
& UPA-sarpanch villages & non-UPA sarpanch villages \\
& If voted & If voted \\
\hline Household Political Category & (base: $\begin{array}{l}\text { UPA, Politically Inactive) } \\
\text { UPA Politically Active }\end{array}$ & -0.0103 \\
& -0.00594 & $(0.0266)$ \\
UPA-Rival, Politically Inactive & $(0.0131)$ & -0.0259 \\
& 0.0143 & $(0.0320)$ \\
UPA-Rival, Politically Active & $(0.0144)$ & -0.00498 \\
& 0.00863 & $(0.0210)$ \\
Unaffiliated & $(0.0142)$ & $0.0632 *$ \\
& 0.0219 & $(0.0376)$ \\
F-test of all political variables & $(0.0149)$ & 1.74 \\
P-value of the F-test & 1.51 & 0.1477 \\
$R^{2}$ & 0.1991 & 0.6331 \\
Sample Size & 0.7174 & 598 \\
\hline
\end{tabular}

Note: Robust standard errors clustered at the village level are in parentheses. If voted is a binary variable taking the value 1 if the household head voted in the recent Gram Panchayat election, 0 if not. All regressions include village fixed effects. Politically Active refers to intense party activities such as attending rallies, campaigning, attending meetings, giving speeches and writing pamphlets; Politically Inactive households do not participate in political activities. The Unaffiliated category includes those not affiliated with any party or those affiliated with fringe parties that are non-UPA and non-UPA-rival. The involvement level of all unaffiliated households was set to "Politically Inactive". Control variables include caste, poverty status, household size categories, proportion of adults, primary occupation and education of the household head, education of the spouse, land ownership categories, availability of electricity connection, location in a hamlet, and hours spent reading a newspaper in the past week. The F-test of all political variables has (4, 260) degrees of freedom in column 1 and $(4,87)$ degrees of freedom in column 2. 


\title{
For earlier Discussion Papers
}

\author{
please click here
}

\begin{abstract}
All discussion papers can be downloaded free of charge
\end{abstract}


INTERNATIONAL FOOD POLICY

RESEARCH INSTITUTE

www.ifpri.org

IFPRI HEADQUARTERS

1201 Eye Street, NW

Washington, DC 20005 USA

Tel.: +1-202-862-5600

Fax: +1-202-862-5606

Email: ifpri@cgiar.org 